\title{
QUALIDADE DA ÁGUA NO TRANSPORTE DE: ALEVINOS DE TILÁPIA DO NILO (Oreochromis niloticus) EM SACOS PLÁSTICOS
}

\author{
Alexsandra Carmen Caseiro \\ Engenheiro Agrônomo
}

Orientador: Prof. Dr. JOSÉ EURICO POSSEBON CYRINO

Dissertação apresentada à Escola Superior de Agricultura "Luiz de Queiroz", Universidade de São Paulo, para a obtenção do título de Mestre em Agronomia, Área de Concentração: Ciência Animal e Pastagens.

\author{
PIRACICABA \\ Estado de São Paulo - Brasil \\ Dezembro - 2000
}




\section{ERRATA}

\begin{tabular}{|c|c|c|c|c|}
\hline Página & Parágrafo & Linha & Onde se lê & Leia-se \\
\hline vi & 1 & 2 & OREOCHROMIS NILOTICUS & Oreochromis niloticus \\
\hline vi & 16 & 2 & OREOCHROMIS NILOTICUS & Oreochromis niloticus \\
\hline viii & 2 & 3 & O. niloticus & O. niloticus \\
\hline xiii & 1 & 5 & O. niloticus & O. niloticus \\
\hline xiii & 1 & 6 & fastening & fasting \\
\hline xiii & 1 & 9 & tempered & salinized \\
\hline 7 & 4 & 2 & $\begin{array}{l}\text { absorção, excreção e } \\
\text { crescimento. }\end{array}$ & absorção e excreção. \\
\hline 14 & 3 & 1 & estudou & estudaram \\
\hline 15 & 5 & 1 & transporte proteger & transporte para proteger \\
\hline 26 & 3 & 2 & $\begin{array}{l}\text { absorção, excreção e } \\
\text { crescimento. }\end{array}$ & absorção e excreção. \\
\hline 26 & 4 & 2 & proteína & PB \\
\hline 27 & 1 & 1 & do jejum é maior & do jejum pode ser maior \\
\hline 28 & 1 & 2 & comportamento & constatação \\
\hline 28 & 1 & 8 & kit & "kit" \\
\hline 28 & 2 & 6 & através do & pelo \\
\hline 31 & 4 & 5 & gastro-intestinal & gastrointestinal \\
\hline 34 & 1 & - & $\begin{array}{l}\text { Excluir: } \\
\text { embora não tenha sido notado o ef } \\
\text { dos peixes durante o transporte, en } \\
\text { a manutenção de uma água de mel } \\
\text { possa reduzir a incidência de doen } \\
\text { pós-transporte. }\end{array}$ & $\begin{array}{l}\text { eito do jejum na sobrevivência } \\
\text { n algumas ocasiões é possível que } \\
\text { hor qualidade e menor carga fecal } \\
\text { ças e mortalidade dos alevinos }\end{array}$ \\
\hline 42 & 1 & 3 & $\begin{array}{l}\text { benzocaína (aminobenzoato } \\
\text { etílico) }\end{array}$ & $\begin{array}{l}\text { aminobenzoato etílico } \\
\text { (benzocaína) }\end{array}$ \\
\hline 48 & 2 & 3 & $\begin{array}{l}\text { diverge daquilo que era esperado } \\
\text { antes do início do experimento. }\end{array}$ & $\begin{array}{l}\text { diverge do que já foi preconizado } \\
\text { na literatura. }\end{array}$ \\
\hline 48 & 2 & 6 & conforme esperado. & $\begin{array}{l}\text { conforme já foi constatado por } \\
\text { vários autores. }\end{array}$ \\
\hline 49 & 1 & 5 & nívies & níveis \\
\hline 49 & 2 & 4 & observou & observaram \\
\hline 57 & 1 & 3 & grande diferencial & grande diferença \\
\hline
\end{tabular}




\section{Dados Internacionais de Catalogação na Publicação (CIP) DIVISĀO DE BIBLIOTECA E DOCUMENTAÇĀO - Campus "Luiz de Queiroz"/USP}

\section{Caseiro, Alexsandra Carmen}

Qualidade da água no transporte de alevinos de tllápia do Nilo (Oreochromis niloticus) em sacos plásticos / Alexsandra Carmen Caseiro. -.- Piracicaba, 2000. $66 \mathrm{p}$.

Dissertação (mestrado) - - Escola Superior de Agricultura Luiz de Queiroz, 2000. Bibliografia.

1. Alevino 2. Benzocaína 3. Embalagem plástica 4. Qualidade da água 5. Tilápiado-nilo 6. Transporte animal I. Título

CDD 639.31

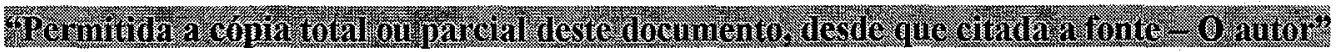




\section{DEDICATÓRIA}

Dedico este trabalho e todos os anos de estudo aos meus pais

\section{Elci e Manoel}

pelo apoio, compreensão e amor em todos os meus anos de vida

e ofereço para as minhas irmãs

\section{Andréa e Adriana}

e ao meu companheiro

\section{Paulo Moreno}

pelos anos de apoio e convívio. 


\section{AGRADECIMENTOS}

A Deus, por ter me orientado em todos os momentos da minha vida;

Ao Departamento de Produção Animal da ESALQ/USP pela oportunidade de realizar este curso;

À Fundação de Amparo a pesquisa, pela concessão da bolsa de estudos;

Ao Prof. Dr. José Eurico Possebon Cyrino por ter me acolhido como estagiária e orientada durante o mestrado, e principalmente pela aprendizagem;

Aos Professores do Departamento de Produção Animal da ESALQ/USP pelos ensinos prestados e ajuda no decorrer do curso;

Aos Funcionários do Departamento de Departamento de Produção Animal da ESALQ/USP pelo auxílio em todos os trabalhos;

Ao amigo Fernando Kubitza, pelo tanto que me ensinou, apoiou e pela crença em meu trabalho;

Às amigas Márcia lafigliola e Adriana Pontes pelos anos de convivio e companheirismo;

Às amigas Tatiana Guimarães e Ludimila Kubitza que muito me ajudaram para o desenvolvimento de parte do trabalho;

Ao amigo Leandro Portz, pelo incentivo e ajuda para a conclusão desta dissertação;

A Nutron Alimentos Ltda, na pessoa do Dr Luciano Roppa pela compreensão e incentivo para a conclusão deste trabalho;

Enfim, a todas as pessoas que, direta ou indiretamente, contribuíram para o sucesso deste trabalho, o meu sincero agradecimento. 


\section{SUMÁRIO}

Página

LISTA DE TABELAS VIII

LISTA DE FIGURAS IX

RESUMO xii

SUMMARY xiv

CAPÍTULO 1. INTRODUÇÃO 1

CAPÍTULO 2. REVISÃO DE LITERATURA 4

1. A tilápia do Nilo-_- 4

2. Fatores que afetam as cargas dos peixes --_ 5

2.1. Oxigênio dissolvido $(O D)$ - 5

2.3. Tamanho do peixe-- 6

2.4. Grau de repleção alimentar -- 7

3. Cargas para o transporte de alevinos em sacos plásticos -

4. Estresse durante as operações de transporte - 11

4.1. Estresse físico --

4.2. Estresse fisiológico-12

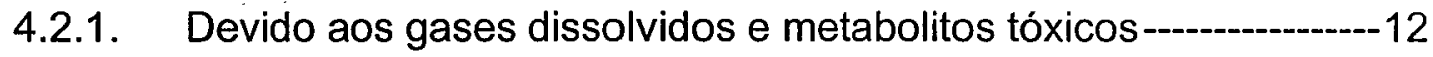

4.2.2. Alterações hormonais e fisiológicas -.

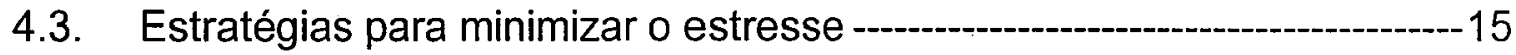

4.3.1. Uso de sal -- 15

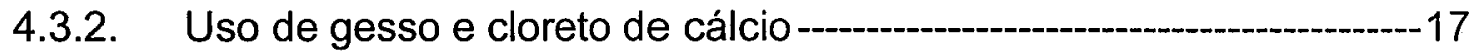

4.3.3. Uso de anestésicos - 18

4.3.4. Jejum antes do transporte--

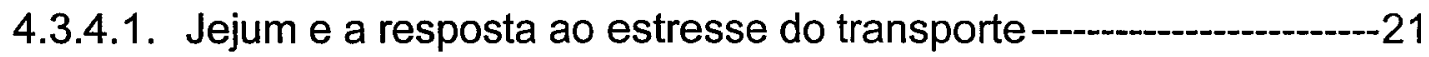


CAPITULO 3. TRANSPORTE DE ALEVINOS DE TILÁPIA DO NILO (OREOCHROMIS NILOTICUS) EM SACOS PLÁSTICOS. 1 - ESTUDO COMPARATIVO DOS PARÂMETROS DE QUALIDADE DA ÁGUA DO TRANSPORTE EM FUNÇÃO DO GRAU DE REPLEÇÃO ALIMENTAR. $-24$

Resumo $-24$

Abstract $-25$

Introdução $-25$

Material e métodos $-27$

Peixes e unidades experimentais $-27$

Delineamento experimental e análises estatísticas $-28$ Resultados $-28$

Oxigênio dissolvido $-30$

Metabolitos nitrogenados e gás carbônico$-31$

Temperatura da água $-33$

Conclusões $-34$

Agradecimentos $-34$

Referências bibliográficas $-34$

Anexos A 37

CAPITULO 4. TRANSPORTE DE ALEVINOS DE TILÁPIA DO NILO (OREOCHROMIS NILOTICUS) EM SACOS PLÁSTICOS. II - ESTUDO COMPARATIVO DO USO DE DOSES DE BENZOCAÍNA (AMINOBENZOATO ETÍLICO) INTERFERINDO NAS CARGAS DE TRANSPORTE E NOS PARÂMETROS DE QUALIDADE DA ÁGUA.

Resumo

Abstract

Introdução

Material e métodos

Peixes e unidades experimentais 
Cargas de peixes e doses do anestésico --

Variáveis avaliadas--

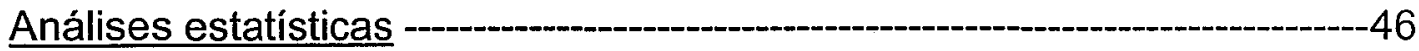

Resultados---_- 46

Discussão --_- 48

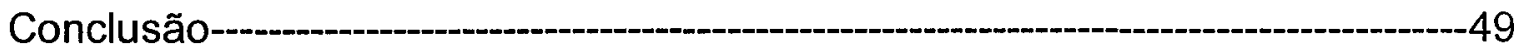

Agradecimentos --

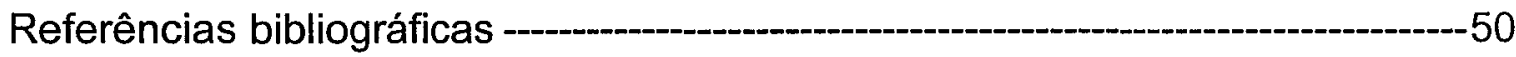

Anexos B -

CAPITULO 5. CONCLUSÃO GERAL -

REFERÊNCIAS BIBLIOGRÁFICAS - 


\section{LISTA DE TABELAS}

Página

Capítulo 4. Transporte de alevinos de tilápia do Nilo (Oreochromis niloticus) em sacos plásticos. II - Estudo comparativo do uso de doses de benzocaina (aminobenzoato etílico) interferindo nas cargas de transporte e nos parâmetros de qualidade da água.

Tabela 1. Comparação entre as médias de tempo de transporte e parâmetros de qualidade de água para os tratamentos com uso de diferentes doses de benzocaína no transporte de alevinos de tilápia ( $O$. niloticus) em sacos plásticos nas cargas 270 e $450 \mathrm{~g} / \mathrm{L}$. 


\section{LISTA DE FIGURAS}

Página

Capítulo 3. Transporte de alevinos de tilápia do Nilo (Oreochromis niloticus) em sacos plásticos. I - Estudo comparativo dos parâmetros de qualidade da água do transporte em função do grau de repleção alimentar.

Figura 1. Variação nos níveis de oxigênio dissolvido na água do transporte em sacos plásticos com peixes sem jejum ou em jejum de 48 horas.

Figura 2. Variação nos niveis de $\mathrm{CO}_{2}$ na água do transporte em sacos plásticos com peixes sem jejum ou em jejum de 48 horas.

Figura 3. Variação na temperatura da água do transporte ao longo do tempo para sacos plásticos com peixes sem jejum ou em jejum de 48 horas.

Figura 4. Variação na temperatura da água do transporte ao longo do tempo para sacos plásticos com peixes sem jejum ou em jejum de 48 horas.

Figura 5.Variação nos niveis de amônia total na água do transporte em sacos plásticos com peixes sem jejum ou em jejum de 48 horas.

Figura 6. Variação nos níveis de amônia tóxica na água do transporte em sacos plásticos com peixes sem jejum ou em jejum de 48 horas.

Figura 7. Variação na taxa de excreção de metabolitos durante o transporte de alevinos em sacos plásticos para os intervalos de tempo onde foram tomadas as medições da qualidade da água. 
Capítulo 4. Transporte de alevinos de tilápia do Nilo (Oreochromis niloticus) em sacos plásticos. II - Estudo comparativo do uso de doses de benzocaína (aminobenzoato etílico) interferindo nas cargas de transporte e nos parâmetros de qualidade da água.

Figura 1. Comparação das médias de tempo de transporte para as cargas 235 e $470 \mathrm{~g} / \mathrm{L}$ (números) e para as diferentes doses de benzocaína dentro das referidas cargas (letras) - números e letras diferentes: $P<0,05$

Figura 2. Comparação das médias de oxigênio dissolvido na água do transporte para as cargas 235 e $470 \mathrm{~g} / \mathrm{L}$ (números) e para as diferentes doses de benzocaina dentro das referidas cargas (letras) - números e letras diferentes: $P<0,05$.

Figura 3. Comparação das médias de gás carbônico na água do transporte para as cargas 235 e $470 \mathrm{~g} / \mathrm{L}$ (números) e para as diferentes doses de benzocaina dentro das referidas cargas (letras) - números e letras diferentes: $P<0,05$.

Figura 4. Comparação das médias de amônia total na água do transporte para as cargas 235 e $470 \mathrm{~g} / \mathrm{L}$ (números) e para as diferentes doses de benzocaína dentro das referidas cargas (letras) - números e letras diferentes: $P<0,05$.

Figura 5. Comparação das médias de amônia tóxica na água do transporte para as cargas 235 e $470 \mathrm{~g} / \mathrm{L}$ (números) e para as diferentes doses dentro das referidas cargas (letras) - números e letras diferentes: $\mathrm{P}<0,05$. 


\title{
QUALIDADE DA ÁGUA NO TRANSPORTE DE ALEVINOS DE TILÁPIA DO NILO (Oreochromis niloticus) EM SACOS PLÁSTICOS
}

\author{
Autor: Alexsandra Carmen Caseiro \\ Orientador: Professor Dr. José Eurico Possebon Cyrino
}

Apesar de ser uma operação de extrema importância, o transporte de peixes vivos é freqüentemente negligenciado em muitas pisciculturas. A alta mortalidade de alevinos durante e após o transporte contribuem para o aumento dos custos de produção e diminuição dos lucros das piscigranjas produtoras de alevinos ou dedicadas à recria e engorda. A presente dissertação avaliou estratégias auxiliares no transporte de alevinos de tilápia ( $O$. niloticus), espécie de grande interesse comercial no Brasil e no mundo. Em dois experimentos foram avaliados o efeito do jejum e do uso do anestésico benzocaina sobre a qualidade da água, duração do transporte e a sobrevivência dos peixes durante e após o transporte. Os peixes foram estocados em embalagens plásticas de 8 litros, contendo $1,5 \mathrm{~L}$ de água (sem cloro e com $0,3 \%$ de sal), as quais tiveram seu volume completado com oxigênio. Em ambos os experimentos foram monitorados o oxigênio dissolvido (OD), a temperatura da água, o $\mathrm{pH}$, a concentração de gás carbônico $\left(\mathrm{CO}_{2}\right)$, de amônia total $\left(\mathrm{NH}_{3 \text { total }}\right)$ e de amônia não-ionizada $\left(\mathrm{NH}_{3}\right)$. A sobrevivência dos peixes durante e após o transporte foi registrada.

No primeiro estudo, alevinos de tilápia do Nilo (O. niloticus) de 4,5 a $6,0 \mathrm{~g}$, alimentados ou submetidos a um jejum de 48 horas, foram estocados nas embalagens a uma carga fixa de $175 \mathrm{~g} / \mathrm{L}$. Os parâmetros de qualidade da água acima mencionados foram mensurados às $4,8,12,16$ e 20 horas do início do experimento. Nas embalagens com peixes em jejum o oxigênio foi maior e houve um menor acúmulo de $\mathrm{CO}_{2}, \mathrm{NH}_{3}$ total e $\mathrm{NH}_{3}$ na água, comparadas as embalagens com peixes alimentados $(P<0,05)$. Nos 5 intervalos de tempo avaliados, foram observadas diferenças significativas em todos estes 
parâmetros $(P<0,05)$. A interação entre o tempo de transporte e a condição alimentar dos peixes foi significativa $(P<0,05)$ para todas as variáveis de qualidade de água, exceto para o $\mathrm{pH}$.

No segundo experimento foram avaliados os efeitos de três doses de benzocaína ( 0,10 e $20 \mathrm{mg} / \mathrm{L}$ ) e duas cargas de peixes ( 235 e $470 \mathrm{~g} / \mathrm{L}$ ) sobre a qualidade da água e a duração do transporte de alevinos de tilápia do Nilo ( $O$. niloticus), de 4,4 a 5,0 g. Foram observadas diferenças significativas no tempo de transporte, $\mathrm{OD}, \mathrm{CO}_{2}, \mathrm{NH}_{3 \text { total }}$ e $\mathrm{NH}_{3}$ entre as cargas de peixes $(\mathrm{P}<0,05)$, mas não entre as doses de benzocaína avaliadas $(P>0,05)$, a não ser pela tendência de redução nos níveis de $\mathrm{NH}_{3}$ total na água do transporte com o aumento das doses de anestésico para a maior carga de peixe $(P<0,05)$. Os elevados niveis de $\mathrm{CO}_{2}$ na água do transporte $(131 \mathrm{mg} / \mathrm{L}$ a $207 \mathrm{mg} / \mathrm{L})$ podem ter exercido ação tranquilizante nos peixes, mascarando os efeitos do uso da benzocaína. 


\title{
WATER QUALITY DURING LIVE TRANSPORTATION OF NILE TILAPIA (Oreochromis niloticus) FINGERLINGS IN PLASTIC BAGS.
}

\author{
Author: Alexsandra Carmen Caseiro \\ Adviser: Professor Dr. José Eurico Possebon Cyrino
}

The importance of live fish transportation is frequently underestimated by fish culturists. The high mortality of fingerlings during and after transportation adds to the production costs and diminishes the profits during production of fingerlings and food fish. The present work has focused on the strategies to improve the success of live transportation of Nile tilapia (Oreochromis niloticus) fingerlings. Two experiments evaluated the effect of fastening fish previously to transportation and the benefits of using benzocaine as an anesthethic on the water quality, duration of transport and fish survival. In both experiments fish were stocked into 8- $\mathrm{L}$ plastic bags with $1,5 \mathrm{~L}$ of declorinated water tempered with salt at $3 \mathrm{~g} / \mathrm{L}$. After fish were loaded, the bags were filled with oxygen to a volume of $8 \mathrm{~L}$ and sealed with rubber bands. Dissolved oxygen (DO), water temperature, $\mathrm{pH}$, carbon dioxide $\left(\mathrm{CO}_{2}\right)$, total ammonia nitrogen $\left(\mathrm{N}-\mathrm{NH}_{3 \text { total }}\right)$ and unionized ammonia nitrogen $\left(\mathrm{N}-\mathrm{NH}_{3}\right)$ were monitored. Fish mortality during and after the trial was also recorded.

In the first experiment 4.5 to $6.0 \mathrm{~g}$ Nile tilapia fingerlings, non-fasted or fasted for 48 hour previous to transportation, were stocked into the bags at a rate of $175 \mathrm{~g}$ of fish/L of water. Water quality parameters were monitored at 4,8 , 12,16 and 20 hours from the beginning of the experiment. The water in the bags with fasted fish had higher $\mathrm{DO}$ levels and lower $\mathrm{CO}_{2}, \mathrm{NH}_{3 \text { total }}$ ) and $\mathrm{NH}_{3}$ compared to water from bags with non-fasted fish $(P<0.05)$. Such differences were maintained along the time $(P<0.05)$. There was a significant interaction between time of transport and fish condition for all the water quality parameters, but water $\mathrm{pH}$. Water with non-fasted fish had a faster decline in $\mathrm{OD}$ and 
accumulated more $\mathrm{CO}_{2}$ and $\mathrm{NH}_{3}$ tota compared to water with fasted fish. Water $\mathrm{NH}_{3}$, temperature and $\mathrm{pH}$ showed great variation in bags containing fasted fish. In the second experiment, the effects of benzocaine on the water quality were evaluated during live transportation of $5 \mathrm{~g}$ tilapia fingerlings in plastic bags. Fish were fasted 72 hours prior to the study and were loaded into 8-L plastic bags at 235 or $470 \mathrm{~g}$ of fish $/ \mathrm{L}$ of water. Benzocaine was tested at 10 or $20 \mathrm{mg} / \mathrm{L}$. Control treatments without the use of benzocaine were set for both fish loads. Significant differences on the time of transport and water $\mathrm{DO}, \mathrm{CO}_{2}, \mathrm{NH}_{3 \text { total }}$ and $\mathrm{NH}_{3}$ were observed between the two fish loads tested $(P<0.05)$. The benzocaine had no influence on the water quality parameters, except for the trend of reducing the $\mathrm{NH}_{3 \text { total }}$ in the water with the increase in the doses of benzocaine for the higher fish loads $(P<0.05)$. The high levels of carbon dioxide in the water $(131 \mathrm{mg} / \mathrm{L}$ to $207 \mathrm{mg} / \mathrm{L}$ ) may have effected a tranquilizing action on fish, masking the effects of using benzocaine. 


\section{Capítulo 1. Introdução}

No início dos anos 80 , com a introdução da tecnologia para a produção de tilápias, carpas, truta arco-íris e bagres americano e africano e o desenvolvimento da desova induzida de pacu (Piaractus mesopotamicus) e do tambaqui (Colossoma macroporum), a piscicultura brasileira assumiu caracter comercial (Castagnolli, 1995). Nesta época, enquanto a produção mundial de peixes de água doce (capturados e produzidos) já era de 6.200 .462 toneladas/ano, a captura de pescado em águas interiores brasileiras era de 177.710 toneladas/ano (FAO, 2000).

Dezesseis anos depois, quando os dados estatísticos da FAO apontavam uma produção mundial de peixes de água doce de 20.528 .440 toneladas ao ano, a produção brasileira girava em torno de 207.600 toneladas anuais (Ministério da Agricultura, 2000). Deste montante, 51.300 toneladas eram provenientes da produção em cativeiro, correspondendo a $24,7 \%$ do total.

Em 1997, a estimativa de produção da piscicultura nacional foi de 76.530 toneladas (Ministério da Agricultura, 2000), o que representou um crescimento de $32,9 \%$ em relação ao ano anterior. O desenvolvimento de um forte setor de pesca recreativa viabilizou a comercialização da maior parte do peixe cultivado e estimulou ainda mais o crescimento da aquicultura, principalmente nas regiões sul, sudeste e, posteriormente, centro-oeste do Brasil.

A crescente demanda de peixes para abastecer este mercado aumentou a necessidade de produção de alevinos e juvenis para as unidades de engorda nas diversas regiões do Brasil. Surgia então a preocupação de melhorar as 
estratégias de transporte de alevinos para longas distâncias, reduzindo os custos e a mortalidade durante e após o transporte.

Peixes tropicais podem ser transportados de várias formas. Segundo McGee e Cichra (sem data), peixes menores podem ser facilmente transportados em sacos plásticos contendo água e oxigênio. $O$ transporte de pós-larvas e alevinos em sacos plásticos enviados por aviões, ônibus e caminhões é o mais utilizado. No entanto, para um grande número de alevinos e juvenis, o ideal é fazer o transporte em tanques com aeração ou suprimento de oxigênio (Stickney, 1986).

Para o transporte de peixes em sacos plásticos são utilizadas embalagens de tamanhos variáveis, sendo preferível aquelas com fundo quadrado e com espessura de 0,2 milimetros para minimizar o risco de perfurações. Os sacos plásticos geralmente são preenchidos em um quarto do seu volume com água. Os peixes são adicionados e a embalagem recebe uma carga de oxigênio, correspondente a três quartos do seu volume. Em seguida é selada com tiras de borracha e colocada em caixas de papelão vedadas. Para um transporte em sacos plásticos bem sucedido é necessário: (1) o suprimento adequado de oxigênio, (2) a inibição ou redução da taxa de excreção dos metabolitos potencialmente tóxicos e (3) a redução da população de bactérias (Teo et al., 1989). Segundo Fröse (1985) este método de transporte é acompanhado por dois problemas: a alta mortalidade e o elevado custo.

A demanda pela tilápia no mercado nacional e internacional é notória. Com base em dados apresentados por Lovshin (1997), a produção mundial de tilápia cultivada em 1996 foi de 800.000 toneladas. De acordo com Fitzsimmons (2000) a produção mundial de tilápia cultivada em 2000 deve exceder a marca de 1.000 .000 de toneladas, o que representa um crescimento de $20 \%$ em 4 anos.

Embora a produção brasileira de tilápia cultivada ainda seja pequena (30.000 a 40.000 toneladas anuais - Kubitza, 2000), o Brasil posiciona-se como um dos países de maior potencial para a produção comercial deste peixe, 
devido às condições climáticas, os abundantes recursos hídricos e à disponibilidade de grãos com excelente qualidade e reduzido preço para a elaboração de dietas completas para a nutrição deste peixe. Acreditando nisto, membros da "American Tilapia Association" e do "International Center for Living Resources Management - INCLARM" promoveram, em setembro de 2000, o V Simpósio Internacional de Tilápia na Aquicultura no Rio de Janeiro.

O desenvolvimento de estratégias seguras de transporte de alevinos é fundamental para o sucesso das piscigranjas produtoras de alevinos e para a redução dos custos de produção nas fases de recria e engorda. Assim, o presente trabalho objetivou estabelecer critérios seguros para o transporte de alevinos de tilápia (Oreochromis niloticus) em sacos plásticos, buscando avaliar as condições da qualidade de água do transporte para peixes em jejum e alimentados, bem como o benefício do uso de anestésicos. 


\section{Capítulo 2. Revisão de literatura}

\section{A tilápia do Nilo}

Espécie exótica endêmica do continente africano, a tilápia é considerada um dos peixes de maior potencial para a aquicultura (Popma e Lovshin, 1996). De acordo com Castagnolli (1992), este peixe foi introduzido no Brasil em 1971, em Pentecostes-CE, pelo Departamento Nacional de Obras Contra a Seca D.N.O.C.S..

Dentre todas as espécies de tilápia, a tilápia do Nilo (Oreochromis niloticus) é a mais produzida no mundo (Kubitza, 2000). O crescimento rápido, a grande rusticidade, a tolerância às condições ambientais adversas e o hábito alimentar planctófago/onivoro são características que tornam este peixe atrativo para a produção comercial. Do ponto de vista produtivo, a precocidade reprodutiva, a excessiva prolificidade e a diferença na taxa de crescimento entre machos e fêmeas aparecem como desvantagem, fator esse que leva à necessidade de submeter os alevinos ao processo de reversão sexual.

O melhor desenvolvimento deste peixe é conseguido na temperatura de 26 a $28^{\circ} \mathrm{C}$ (Beerli e Logato, 1999). Quando alimentado com ração completa e sob condições adequadas de qualidade da água, a tilápia do Nilo pode alcançar $500 \mathrm{~g}$ em 6 meses de cultivo. Peixes com peso entre 450 e $500 \mathrm{~g}$ são comercializados junto aos pesque-pagues, frigoríficos e supermercados. 


\section{Fatores que afetam as cargas dos peixes}

A carga de peixes que pode ser transportada é função da disponibilidade de oxigênio dissolvido (OD), da temperatura da água, do tamanho dos peixes, do grau de repleção alimentar, da duração do transporte, da espécie entre muitos fatores.

\subsection{Oxigênio dissolvido (OD)}

Dentre os fatores de qualidade da água, o oxigênio é o mais limitante no transporte de peixes, devendo ser mantido em concentrações adequadas à sobrevivência dos peixes. Os valores mínimos desejados na água de transporte estão entre 6 e $7 \mathrm{mg} / \mathrm{L}$ (Jensen, 1990a), entretanto niveis de até $15 \mathrm{mg} / \mathrm{L}$ podem ser benéficos para viagens longas (Frankfort, 1989).

Durante o manuseio e o carregamento dos peixes, o consumo de oxigênio aumenta dramaticamente (Johnson, 1979). Em condições de transporte, o consumo é 3 vezes maior do que em condições normais (Fröse, 1985).

\subsection{Temperatura da água}

A temperatura da água exerce forte influência no metabolismo dos peixes, devendo ser constantemente controlada e monitorada no transporte (Piper et al., 1989). Devido a pecilotermia dos peixes, aumentos na temperatura da água influenciam de maneira direta atividade metabólica dos peixes, resultando em maior consumo de oxigênio e excreção de metabolitos. De maneira geral, a cada aumento em $10^{\circ} \mathrm{C}$ na temperatura da água, é possivel observar um aumento em até duas vezes na atividade metabólica dos peixes. De acordo com Snow (1971), temperaturas mais baixas possibilitam transportar cargas maiores de peixes com grande sucesso. 
O aumento no consumo de oxigênio pelos peixes é proporcional ao aumento na temperatura da água. Ross e Ross (1983), estudaram a influência da temperatura da água na taxa de consumo de oxigênio de alevinos de tilápia com $10 \mathrm{~g}$ em jejum de 48 horas. Os autores observaram taxas de consumo de oxigênio de 167, 280, 567 e $600 \mathrm{mg} / \mathrm{kg} /$ hora para as temperaturas de 20, 25, 30 e $35^{\circ} \mathrm{C}$, respectivamente.

Algumas espécies são mais sensiveis a choques de temperatura, enquanto outras são mais resistentes. De forma geral, peixes menores são mais sensiveis do que os maiores (Jensen, 1990b). De acordo com Frankfort (1989), o bagre do canal (/ctalurus punctatus) deveria ser transportado a temperaturas da água entre 15 e $22^{\circ} \mathrm{C}$ no verão e 7 e $10^{\circ} \mathrm{C}$ no inverno. "Golden shiners" são sensiveis a temperaturas superiores a $16^{\circ} \mathrm{C}$, porém podem suportar quedas bruscas de até $9^{\circ} \mathrm{C}$ na temperatura da água. Por outro lado, o "fathead minows" (Pimephales promelas) e o "goldfish" (Carassius auratus), peixes bastante usados como iscas vivas nos Estados Unidos, requerem mudança gradual (Jensen, 1990b).

Peixes como a tilápia, o pacu, o tambaqui, o tambacu, o matrinxã, a piraputanga, o piauçu e o tucunaré são pouco tolerantes a temperaturas muito baixas. Normalmente, a temperatura da água é abaixada até $25^{\circ} \mathrm{C}$. De acordo com Kubitza (1999), não é recomendável o transporte de pacu, tambaqui e espécies do gênero Brycon a temperaturas superiores a $28^{\circ} \mathrm{C}$.

\subsection{Tamanho do peixe}

Se as condições ambientais forem constantes, o tamanho do peixe será o principal fator limitante da carga de peixes a ser transportada (Stickney, 1986; Frankfort, 1989, Swan, 1992). O consumo de OD pelos peixes é influenciado pelo tamanho, nivel de atividade, espécie de peixe e temperatura da água.

Peixes menores consomem mais OD por quilo de peso vivo do que peixes maiores. Isto se deve às taxas metabólicas mais elevadas dos peixes mais 
jovens. Sendo assim, larvas e pós-larvas consomem mais OD durante o transporte do que alevinos, e estes últimos mais do que peixes adultos (Brown et al., 1984).

Méllard (1986) citado por Kubitza (2000) quando estudou o consumo de oxigênio para diferentes tamanhos de tilápia do Nilo na temperatura de $25^{\circ} \mathrm{C}$ pode constatar que peixes com 10,50, 100 e 150g consomem 280,160, 125 e $110 \mathrm{mg}$ de oxigênio/kg de peixe/hora. Este diferencial no consumo de oxigênio sustenta a afirmação de Bocek (1996) que as cargas de transporte para peixes menores serão menores se comparadas às cargas com peixes maiores.

\subsection{Grau de repleção alimentar}

Imediatamente após a ingestão dos alimentos, o organismo animal inicia sua digestão, processo fisiológico que envolve as vias de absorção, excreção e crescimento. Durante o período de passagem do alimento pelo trato digestivo, verifica-se o aumento na taxa de consumo de oxigênio (Solomon e Taylor, 1979; Jobling, 1981) e na taxa de excreção de metabólitos (Gélineau et al., 1998).

Jarboe (1995) estudou as alterações no consumo de oxigênio e na taxa de excreção de amônia total para juvenis de bagre do canal após a alimentação. Usando peixes de aproximadamente $66 \mathrm{~g}$, mantidos em água a $27^{\circ} \mathrm{C}$, observou que o pico de excreção de amônia ocorreu 10 horas após a alimentação. $O$ mesmo foi observado com o consumo de oxigênio que permaneceu elevado até 12 horas decorrentes do fornecimento de alimento, e somente retornou aos níveis iniciais 14 horas após a alimentação.

Juvenis de truta arco-íris, mantidos em água a $15^{\circ} \mathrm{C}$, também apresentaram alterações metabólicas decorrente da alimentação. Uma hora após a alimentação, foi detectado aumento no consumo de oxigênio, o qual se manteve até 3 horas após a alimentação, diminuindo após este período. No que diz respeito à excreção de metabolitos, foram observados incrementos nas 
taxas de excreção de $\mathrm{CO}_{2}$ dentro de um intervalo de 1 hora decorrente da alimentação. Por outro lado, o aumento na excreção de nitrogênio amoniacal apenas ocorreu 2 horas após a alimentação, atingindo seu pico de excreção em 5 horas (Gélineau et al., 1998).

A redução nos gastos metabólicos aparece como uma resposta adaptativa do organismo animal mediante a percepção de um período de falta de alimento. Méndez e Wieser (1993) sugeriram 4 fases para descrever a seqüência de respostas dos peixes quando submetidos a privação alimentar. Estas fases foram chamadas de estresse, transição, adaptação e recuperação.

Segundo os autores, quando o alimento não for fornecido por um curto espaço de tempo, os peixes entrarão na fase de estresse que é caracterizada pelo estado de hiperatividade. Este fenômeno foi constatado através do estudo do comportamento de larvas de Rutilus rutilus quando privadas de receber alimento. Durante as primeiras 10 horas de observação, as larvas submetidas ao jejum de 24 horas apresentaram um consumo de oxigênio $50 \%$ maior se comparado ao apresentado por larvas alimentadas com a mesma idade.

Após o período de hiperatividade, passa a vigorar a fase de transição que é marcada pela redução na taxa de consumo de oxigênio. Em seguida, é firmada a estabilidade das rotas metabólicas do organismo, indicando que uma nova rota de energia foi estabelecida. Neste momentos os peixes se encontram na fase de adaptação. Durante esta fase, ocorre a oxidação das gorduras e a redução no uso de proteína. E por fim, quando o animal sai do jejum e é alimentado novamente, ele entra na fase de recuperação, caracterizada por um aumento no consumo de oxigênio e pela retomada do crescimento.

Através de um experimento de avaliação da resposta metabólica de juvenis de 3 espécies de ciprinídeos, Wieser (1992) citado por Méndez e Wieser (1993), observou que a fase de transição pode ser concluída em 2 dias, e que nesta etapa, os peixes em jejum economizam $40 \%$ da energia metabólica gasta pelos peixes alimentados. 
No transporte de peixes vivos, toda a atenção deve ser desviada para as etapas de estresse e transição, visto que o período de jejum dos peixes anterior ao transporte dificilmente supera 3 dias.

A amônia é o principal produto metabólico dos peixes e é excretado pelas brânquias. Esta substância é mais tóxica sob condições de $\mathrm{pH}$ e temperaturas mais elevadas. A concentração de $\mathrm{NH}_{3}$ no transporte pode atingir niveis superiores a $14 \mathrm{ppm}$ (Swan, 1992). A temperatura e o período decorrente da última alimentação são fatores importantes na regulação da excreção da amônia (Piper et al., 1989).

Lied e Braaten (1984) compararam o efeito do grau de repleção alimentar na taxa de excreção de amônia e consumo de oxigênio do bacalhau (Gadus morhua). Peixes em jejum apresentaram uma taxa de excreção considerada equivalente ao metabolismo de manutenção. Peixes alimentados apresentaram um incremento na excreção de amônia, com um pico no intervalo de 5 a 6 horas a partir da alimentação. A demanda por oxigênio também aumentou, sendo observado um pico de consumo de 9 a 10 horas após a alimentação. A excreção de amônia e o consumo de oxigênio somente retornaram aos niveis iniciais 25 horas após a alimentação.

Forsberg (1997) observou que o consumo de oxigênio e a taxa de excreção de $\mathrm{CO}_{2}$ do salmão do Atlântico adulto (Salmo salar), após o arraçoamento, foram 2 vezes maiores do que para peixes em jejum. A excreção de amônia não seguiu a mesma proporção, entretanto, foi crescente em função da intensidade do arraçoamento. De maneira geral, o pico de excreção de amônia para salmonídeos ocorre dentro de um intervalo de 3 a 5 horas após a alimentação e geralmente é 30 a $60 \%$ superior às médias observadas diariamente.

Para prevenir acréscimos nos niveis de amônia na água de transporte, os peixes devem ser submetidos a um período de jejum em água limpa e em temperatura mais baixas. Segundo Fröse (1985), larvas e peixes menores do que $0,1 \mathrm{~g}$ deveriam ser mantidos em jejum de 24 horas antes do transporte, 
peixes de até $3 \mathrm{~g}$ em jejum de 2 dias e peixes maiores que $3 \mathrm{~g}$ em jejum de 3 dias.

\section{Cargas para o transporte de alevinos em sacos plásticos}

A estocagem de peixes para o transporte em șacos plásticos é determinada com base no tamanho dos peixes, na temperatura da água e no tempo estimado de viagem. Cargas de 50 a $90 \mathrm{~g}$ de peixe/L vem sendo usadas para o transporte de peixes em sacos plásticos (Amend et al., 1982). Teo et al. (1989) estudaram o transporte de machos de lebiste (Poecilla reticulata) em sacos plásticos na temperatura de $25^{\circ} \mathrm{C}$. Com o uso de antibiótico, anestésico, uma substância tamponante e trocador de íns, foi possivel transportar lebistes com peso médio de $0,8 \mathrm{~g}$ nas cargas de $83 \mathrm{~g} / \mathrm{L}$ por 24 horas, $60 \mathrm{~g} / \mathrm{L}$ por 36 horas e $41 \mathrm{~g} / \mathrm{L}$ por 48 horas, com taxas de mortalidade entre 3 a $4 \%$.

Em um experimento para avaliar o transporte de peixes ornamentais em condições de campo, Amend et al. (1982) conseguiram transportar peixes de $1 \mathrm{~g}$ submetidos ao jejum de 48 horas, sob a carga de $100 \mathrm{~g}$ de peixes/L por 22 horas e de $87 \mathrm{~g} / \mathrm{L}$ para 35 horas de transporte, sob temperatura de $25^{\circ} \mathrm{C}$. Para garantir a qualidade da água utilizaram uma substância tamponante, antibiótico e um trocador de íns (a clinoptilolita) para a remoção do excedente de amônia da água.

Dupree e Hunner (1984), citados por Swan (1992), estudaram o transporte de alevinos de bagre do canal em sacos plásticos. Os autores recomendam que o transporte seja efetuado com água a temperatura máxima de $18^{\circ} \mathrm{C}$ e dureza total em torno de $100 \mathrm{mg} / \mathrm{L}$. Nestas condições, o transporte de alevinos $0,45 \mathrm{~g}$ por 24 horas, na carga de $75 \mathrm{~g}$ de peixes $/ \mathrm{L}$ foi considerado seguro. Para peixes com peso entre $1,4 \mathrm{~g}$ e 3,2g, a carga recomendada é de $90 \mathrm{~g}$ de peixe/L. Frankfort (1989) recomenda reduzir a carga de transporte em $25 \%$ a cada aumento de $7^{\circ} \mathrm{C}$ na temperatura da água. Em tempos de transporte superiores a 12 horas recomenda uma redução de $25 \%$ na carga. Assim, para uma 
temperatura de $25^{\circ} \mathrm{C}$, a carga para o transporte de 24 horas deveria ser reduzida para $50 \mathrm{~g} / \mathrm{L}$ para alevinos de bagre do canal com peso médio de $0,45 \mathrm{~g}$ e 65g/L para peixes entre 1,4 e 3,2 g.

Sugestões de carga para o transporte de alevinos de pacu em sacos plásticos foram apresentadas por Kubitza (1999). Peixes mantidos em jejum de 24 horas, transportados na temperatura de $25^{\circ} \mathrm{C}$, podem ser transportados por 24 horas nas seguintes cargas: (1) $40 \mathrm{~g} / \mathrm{L}$ para peixes de $2,5 \mathrm{~cm}$; (2) $60 \mathrm{~g} / \mathrm{L}$ para peixes de $5,0 \mathrm{~cm}$, e (3) $130 \mathrm{~g} / \mathrm{L}$ para peixes de $7,5 \mathrm{~cm}$.

\section{Estresse durante as operações de transporte}

O estresse que ocorre em operações de despesca e transporte de peixes tem sido assunto para muitos trabalhos de pesquisa. Estresse é uma condição na qual o animal não consegue manter um estado fisiológico normal devido a vários fatores adversos que afetam o seu bem estar. Ocorre quando o animal é submetido à uma condição aquém do seu nivel normal de tolerância. Os principais procedimentos que desencadeiam o estresse em peixes são o manuseio, o transporte e o tratamento de doenças (Floyd, sem data). Segundo Nikinmaa et al. (1983), a captura inicial e o carregamento dos peixes são as etapas mais estressantes do transporte. $O$ estresse nos peixes transportados em altas densidades pode ser causado por inúmeros fatores, tais como: (a) fatores químicos: baixa qualidade da água (gases dissolvidos, $\mathrm{pH}$ e amônia), poluição, composição inadequada da dieta; (b) fatores biológicos: superpopulação, presença de peixes agressivos, organismos patogênicos microrganismos e macrorganismos; (c) fatores físicos: temperatura e luz (Floyd, sem data).

A mortalidade diretamente ligada ao transporte parece ser inicialmente baixa. Condições de estresse muito intensas, podem causar mortalidade repentina dos peixes durante o transporte. Os peixes geralmente sobrevivem a estas condições. No entanto, grande mortalidade pode ocorrer após o 
transporte devido a disfunções osmorregulatórias e ao estabelecimento de doenças nos peixes enfraquecidos pelo estresse (Carmichael, 1984 b; Stickney, 1986).

\subsection{Estresse físico}

Reúne as injúrias mecânicas decorrente do manuseio e transporte, como a perda de muco e de escamas, bem como raspados e perfurações na pele e na musculatura dos peixes. Normalmente as injúrias aparecem durante e após o manuseio na despesca, pesagem e carregamento para o transporte. Injúrias muito intensas podem até mesmo levar a mortalidade de todos os peixes de uma carga. Injúrias leves podem servir de porta de entrada a agentes patogênicos, causando mortalidade dos peixes após o transporte.

\subsection{Estresse fisiológico}

\subsubsection{Devido aos gases dissolvidos e metabolitos tóxicos}

A habilidade do peixe em utilizar o oxigênio da água depende da sua tolerância ao estresse, da temperatura da água, do $\mathrm{pH}$ e da concentração metabolitos, como o gás carbônico e a amônia. Abundância de oxigênio na água não indica necessariamente que o peixe esteja em boas condições. $O$ fornecimento das quantidades adequadas de oxigênio é de vital importância, uma vez que o déficit deste elemento na água resulta em um estresse severo devido à hipoxia e um subsequente incremento nos niveis de ácido láctico no sangue (Piper et al., 1989). Segundo Wurts (1990), niveis de oxigênio abaixo do mínimo recomendado pode estressar os peixes ou sufocá-los. Paralelamente, niveis superiores ao máximo recomendado poderiam levar à síndrome da bolha de ar ou causar danos nos tecidos.

A amônia total $\left(\mathrm{NH}_{3 \text { total }}\right)$ e o gás carbônico $\left(\mathrm{CO}_{2}\right)$ são metabolitos que se acumulam durante o transporte de peixes (Carneiro e Urbinati, 1999). Este 
acúmulo pode matar os peixes dependendo da carga e do tempo de transporte (Teo et al., 1988). Duas formas de amônia podem ocorrer na água de transporte: a forma ionizada $\left(\mathrm{NH}_{4}{ }^{+}\right)$e a não ionizada $\left(\mathrm{NH}_{3}\right)$. A forma nãoionizada é extremamente tóxica a concentrações tão baixas quanto $0,2 \mathrm{ppm}$. Níveis de $\mathrm{NH}_{3}$ tão elevados quanto 0,5 a $1,0 \mathrm{mg} / \mathrm{L}$ podem ser observados na água do transporte de peixes em sacos plásticos (Bower e Tuner, 1982). De acordo com a Comissão Européia de Produção de Peixes em Águas Continentais (1973) citada por Boyd (1996), niveis de $\mathrm{NH}_{3}$ entre 0,7 e 2,4 mg/L podem levar os peixes à toxidez em um curto período de exposição.

A amônia e outros produtos metabólicos podem reduzir a habilidade dos peixes em utilizar o oxigênio. Leitritz, 1959 citado por Snow, 1971 comenta que se a concentração de amônia no sangue aumentar para 1 ppm, a concentração de oxigênio decresce para $1 / 7$ (um sétimo) do normal e o $\mathrm{CO}_{2}$ aumenta para aproximadamente $15 \mathrm{ppm}$.

O peixe libera $\mathrm{CO}_{2}$ como subproduto da respiração. Elevadas concentrações deste metabolito são maléficas aos peixes e podem tornar-se um fator limitante no transporte. O gás carbônico reduz a capacidade de transporte de oxigênio pelo sangue. Os peixes podem sucumbir se os niveis de $\mathrm{CO}_{2}$ forem muito elevados, ainda que se mantenha niveis adequados de oxigênio (Piper et al., 1989). Se as concentrações e o tempo de exposição forem muito elevados, pode ocorrer mortalidade dos peixes ou mudanças no comportamento, devidos a danos da privação de oxigênio sobre o sistema nervoso (Booke et al., 1978). Quando o $\mathrm{CO}_{2}$ permanece abaixo de $15 \mathrm{ppm}$, o peixe pode ser transportado com sucesso. Acima de $25 \mathrm{ppm}$ normalmente ocorre a morte dos peixes (Snow, 1971). Piper et al. (1989) comenta que algumas espécies de peixes sobrevivem a niveis superiores a $60 \mathrm{mg} / \mathrm{L}$, caso a taxa de acúmulo de $\mathrm{CO}_{2}$ seja lenta. 


\subsubsection{Alterações hormonais e fisiológicas}

A resposta fisiológica dos peixes expostos a um fator estressante pode ser dividida em três etapas: primária, secundária e terciária. Na etapa primária ocorre a liberação de catecolamina e corticosteróides pelas glândulas adrenais. O aumento na concentração dessas substâncias no plasma iniciam a etapa secundária, marcada pela queima de todos os açúcares, como exemplo o glicogênio do fígado, de forma a mobilizar energia para uso do animal em uma eventual ação de emergência. Assim, a etapa secundária é marcada pelo aumento na concentração de glucose no sangue e pelo decréscimo nos niveis de glicogênio no fígado. Também ocorre uma redução na proteína muscular e um aumento no batimento cardíaco e no fluxo de sangue nas brânquias. A osmorregulação é interrompida devido às mudanças no metabolismo mineral. Nestas circunstâncias, os peixes de água doce absorvem água em excesso, permanecendo superidratado. A etapa terciária do estresse é caracterizada por uma redução na resposta inflamatória e na resistência a doenças. Estes efeitos são atribuídos à ação dos hormônios corticosteróides (Mazeaud, 1977 citado por Carmichael et al.; 1984a; Floyd, sem data; Schreck, 1982 citado por Carmichael et al.; 1984b; Stickney, 1986; Mazeaud et al., 1977 citado por Mazik et al., 1991). O número de leucócitos é reduzido, ocorrendo linfocitopenia (redução do número de linfócitos) e neutrofilia (aumento no número de neutrófilos no plasma) - (Thompson et al., 1993).

Dependendo do grau de estresse, ocorre uma mudança nas características do plasma. Nikinmaa et al. (1983) constataram que os niveis de íons cloreto e de íons sódio no plasma decairam durante o manejo e o transporte da truta marrom (Salmo trutta). Carmichael et al. (1983) observaram o mesmo efeito com o "smallmouth bass" (Micropterus dolomieu), além de um acréscimo nos niveis de potássio no plasma.

Carmichael et al. (1984b) estudou o transporte, de longa distância, de alevinos de "largemouth bass" (Micropterus salmoides) com $13 \mathrm{~cm}$, 
transportados por 32 horas na carga de $81 \mathrm{~g} / \mathrm{L}$. Os niveis de corticosteróides no plasma dos peixes aumentaram imediatamente após o manejo inicial, permanecendo elevados por pelo menos 96 horas, estabilizando após mais 24 horas em um nivel indicativo de periodo longo de estresse. Concomitantemente, os niveis de glucose no plasma aumentaram após o manejo inicial. Os niveis de cloreto no plasma tiveram um ritmo decrescente e assim permaneceram até que a água do tanque de transporte fosse trocada.

Em um estudo observando os niveis de corticosteróides, glucose, cloretos e a osmolalidade em "largemouth bass", sob condições ambientais variadas, Carmichael (1984) observou que as respostas ao transporte foram diferentes para peixes aclimatados em águas com temperatura de $10^{\circ} \mathrm{C}$ e $23^{\circ} \mathrm{C}$. As concentrações de glucose aumentaram mais nos peixes mantidos em condições de temperatura da água mais elevadas, e a osmolalidade foi consistentemente mais baixa para peixes mantidos a $10^{\circ} \mathrm{C}$. No entanto, não foram observadas diferenças significativas após 3 horas de transporte. Segundo Carmichael et al. (1984b), a temperatura da água do transporte afeta a osmorregulação.

A incidência de mortalidade de peixes devido a choques de temperatura foi registrada por vários autores. Gareside e Chin Yuen-Kee (1972) citados Carmichael et al. (1984b) atribuem esta mortalidade ao rápido declínio nos níveis de cloreto do plasma e na osmolalidade devido à mudança brusca da temperatura.

\subsection{Estratégias para minimizar o estresse}

\subsubsection{Uso de sal}

Os sais são adicionados à água do transporte proteger os peixes de distúrbios osmóticos. Recomenda-se o uso de uma concentração de sais que se aproximam da composição do sangue dos peixes de água doce (Carmichael 
et al. 1984 citados por Swanson, 1996). O sangue dos vertebrados tem uma salinidade de aproximadamente $9 \mathrm{~g} / \mathrm{L}$ e um $\mathrm{pH}$ de 7,4 . Aproximadamente $77 \%$ dos sais no sangue representam o sódio e o cloreto. O restante é composto primariamente por bicarbonatos, potássio e cálcio. $\mathrm{O}$ sódio e o potássio são críticos para o funcionamento normal do coração, sistema nervoso e músculos. Os sais se difundem de um meio com alta concentração (sangue) para outro de baixa concentração (água). Sódio e cloreto são perdidos lentamente, mas de forma contínua para o ambiente. As perdas de sais são repostas através da reabsorção de sais da água e durante a digestão dos alimentos, processos estes que envolvem gasto de energia. $O$ estresse do transporte e a perda de muco aumentam a perda de sais do sangue, demandando alto dispêndio de energia do peixe que já está enfraquecido para a reposição dos mesmos. Perdas excessivas de sais podem causar danos ao coração e ao sistema nervoso, bem como ocasionar espasmos musculares (Wurts, 1995). A adição de cloreto de sódio sem iodo $(\mathrm{NaCl})$ limita ou previne a perda de sais durante o transporte. O uso de soluções salinas na água de transporte e pós-transporte reduz o gradiente osmótico entre o plasma e o ambiente, reduzindo o gasto de energia para a osmorregulação (Redding e Schreck, 1983 citados por Carmichael et al., 1984a; Jensen, 1990a).

A adição de sal à água de transporte é uma técnica amplamente empregada, reduzindo o estresse e melhorando a sobrevivência dos peixes durante e após o transporte. O sal é um produto barato e não tóxico quando usado em concentrações adequadas (Tomasso et al., 1980 citados por Carmichael e Tomasso, 1988). Concentrações de 0,5 a $2 \mathrm{~g} / \mathrm{L}(0,05$ a $0,2 \%)$ de cloreto de sódio vêm sendo tradicionalmente usadas para reduzir o estresse durante o transporte (Wurts, 1995). Jensen (1990b) recomenda soluções de 0,5 a $10 \mathrm{~g} / \mathrm{L}(0,05$ a $1,0 \%)$, sendo que no caso de peixes de água doce, deve-se usar soluções menos concentradas.

Mazik et al. (1991), compararam a sobrevivência do "striped bass" (Morone saxatalis) em águas de transporte com e sem a aplicação do sal, e 
constataram que houve uma sobrevivência de $100 \%$ e uma minimização do estresse nos lotes que receberam o tratamento de 1,0\% de sal. Na água sem sal a sobrevivência dos peixes foi reduzida. Long et al. (1977) observaram um aumento significativo na sobrevivência de juvenis de "chinook salmon" (Oncorhyncus tshawytscha) quando transportados em água contendo sal. Forsman et al. (1990) compararam as concentrações de sódio ( $\mathrm{Na}$ ) e cloreto (Cl) no músculo de alevinos de perca transportados em água com e sem adição de sal. Os autores constataram que os peixes transportados em água acrescida de $0,4 \%$ de sal não apresentaram desbalanço osmótico significativo.

Avaliando as respostas fisiológicas durante o transporte de truta, Nikinmaa et al. (1983) observaram diferenças na taxa respiratória, nas reservas de energia e nos parâmetros osmóticos entre peixes transportados em água doce e água salobra $(0,6 \%$ de $\mathrm{NaCl})$. Os principais efeitos observados nos peixes transportados em água sem sal foram: (a) maior taxa respiratória; (b) diminuição da osmolalidade do plasma, devido aos decréscimos nos niveis de sódio e cloro; (c) rápido esgotamento das reservas de energia. Deste modo, o efeito benéfico do sal na água de transporte é a redução na mortalidade de peixes e uma atenuação na sobrecarga fisiológica associada ao estresse (Redding e Schereck, 1983).

\subsubsection{Uso de gesso e cloreto de cálcio}

A presença de cálcio na água é de fundamental importância no transporte, possibilitando ao peixe manter seu equilíbrio osmorregulatório. A concentração de cálcio na água pode ser aumentada através da adição de gesso $\left(\mathrm{CaSO}_{4}\right)$ ou cloreto de cálcio $\left(\mathrm{CaCl}_{2}\right)$ - (Carmichael e Tomasso, sem data). A dureza total da água expressa primariamente a concentração de cálcio e magnésio na água, um parâmetro que pode ser facilmente medido com kits de análises. Grizzle et al. (1985) estudaram o efeito da aplicação de $\mathrm{CaCl}_{2}$ na água de transporte, aumentando a dureza da água de 10 para 70 a $200 \mathrm{mg}$ de $\mathrm{CaCO}_{3} / \mathrm{L}$. Tal prática 
resultou em maior sobrevivência de juvenis de "striped bass" e híbridos de "striped bass" após o transporte.

Wurts (1995) afirma que a dureza de cálcio ajuda a controlar a perda de sais do sangue e é necessária para auxiliar na reabsorção de cálcio. A faixa desejável de dureza de cálcio é de 125 a $250 \mathrm{mg} / \mathrm{L}$ de $\mathrm{CaCO}_{3}$, sendo que 250 $\mathrm{mg} / \mathrm{L}$ de dureza de cálcio equivale à concentração de cálcio no sangue. Assim, este pesquisador recomendou uma aplicação de gesso agrícola $\left(\mathrm{CaSO}_{4}\right)$ na água de transporte na proporção de 21 a 43g/L.

\subsubsection{Uso de anestésicos}

Os anestésicos são constantemente empregados quando se deseja a redução no movimento dos peixes (Post, 1987). O maior beneficio de seu uso está no fato de reduzir a atividade metabólica do peixe, resultando em menor consumo de oxigênio dissolvido, menor produção de gás carbônico e reduzida excreção de compostos nitrogenados. Além disso, minimiza a excitação excessiva dos peixes no momento em que estão sendo manuseados (Piper et al., 1989).

O uso de anestésicos acarreta em uma série de alterações fisiológicas no organismo animal. Por este motivo, muito cuidado deve ser tomado para garantir o uso da dose adequada de anestésico para o efeito que se deseja obter.

McFarland (1960) citado por Piper et al. (1989) estudou o efeito do uso de anestésicos em peixes e constatou que a sua resposta pode ser subdividida em 4 etapas: Etapa I - Nivel 1: sedação leve; Nivel 2: sedação profunda; Etapa II Nível 1: perda parcial do equilíbrio; Nível 2: perda total do equilíbrio; Etapa III: perda do reflexo; e Etapa IV: colapso medular.

Iwama et al. (1988) resumiram a classificação de McFarland em 3 estágios: (I) Perda de equilíbrio; (II) Perda dos movimentos do corpo, sem parada nos batimentos operculares; (III) Parada nos movimentos operculares. 
Durve (1975) referenciando a classificação de McFarland (1960), recomenda que a intensidade de anestesia desejada no transporte de peixes vivos engloba o estágio I, os niveis de sedação leve e profunda. Ferreira (1982), citado por Ferreira et al. (1984), não recomenda submeter os peixes à condição de perda parcial do equilibrio (Etapa II - McFarland, 1960). Durante este estágio, os movimentos natatórios são ativados para compensar a perda de equilibrio do peixe, o que resulta em aumento na atividade metabólica, na taxa de consumo de oxigênio e na excreção de metabolitos na água do transporte. Isto sugere a necessidade de adequar as doses de anestésico às respostas desejadas.

Dentre os anestésicos usados em piscicultura, o mais citado na literatura internacional é o MS-222 (tricaína). Este anestésico é o único aprovado pelo FDA (U.S. Food and Drug Administration) para uso em peixe de mesa (Howe et al., 1990; Meinertz et al., 1996). Peixes anestesiados com o MS-222 somente podem ser liberados para o consumo humano 21 dias após a aplicação. Este fator é uma das grandes desvantagens ao uso de MS-222, além do seu elevado preço e da estreita margem entre as concentrações efetivas e tóxicas para os peixes (Gilderhus e Marking, 1987).

De acordo com Taylor e Solomon (1979), na hora da escolha de um anestésico devem ser considerados os seguintes pontos: inexistência de risco ao operador, ausência de resíduos e efeitos maléficos, uso fácil em condições de campo e rápida indução e recuperação da anestesia. Outro aspecto importante é a tolerância do peixe à dose efetiva sob exposição prolongada, além do preço acessivel e fácil obtenção do anestésico.

Em um estudo avaliando a eficácia de 16 anestésicos em truta arco-íris em condições controladas, Gilderhus e Marking (1987) constataram que as 4 melhores substâncias foram o MS-222, a quinaldina, a benzocaína e o 2phenoxyethanol. Dentre estas, os autores listam a benzocaina como a mais vantajosa, por ser efetiva em menores concentrações e apresentar um custo 
$30 \%$ menor do que o MS-222. Um fator adicional é que a benzocaina é amplamente utilizada na medicina humana como anestésico local.

Ainda que não seja um anestésico reconhecido para uso em aquicultura, a benzocaína apresenta-se como um forte substituto ao MS-222. Dawson e Gilderhus (1979) citados por Gilderhus et al. (1991) testaram a benzocaína em 5 espécies de peixes e constataram que esta substância é tão efetiva e segura quanto o MS-222. A semelhança nos resultados pode estar associada ao fato da benzocaína ser estruturalmente semelhante o MS-222 (Mattson e Riple, 1989).

No que diz respeito ao efeito residual da benzocaína, Meinertz (1991) citado por Meinertz et al. (1996) constatou que a mesma é metabolizada por truta arco-íris em no mínimo 3 componentes, sendo parte excretada através das brânquias e uma menor quantidade através da urina. Meinertz et al. (1996) estudaram a cinética da benzocaína em truta arco-íris com peso variando de 500 a $800 \mathrm{~g}$. Neste trabalho, os autores constataram que a aplicação de uma dose de $9 \mathrm{mg} / \mathrm{kg}$ resultou em rápida distribuição e redução dos níveis presentes no plasma pela metade (meia vida) em um período de 89 a 109 minutos.

As doses de benzocaina recomendadas para o transporte englobam ampla faixa, uma vez que a eficácia deste anestésico é função do tamanho dos peixes, da temperatura e da qualidade da água do transporte. Laird e Oswald (1975) citados por Taylor e Solomon (1979) recomendam para o transporte de peixes vivos o uso de 10 a $40 \mathrm{mg} / \mathrm{L}$, independente do tamanho e das condições ambientais.

Entretanto, estudos mais específicos como o desenvolvido por Parma-deCroux (1990) para Prochilodus lineatus com peso variando entre 5,5 e $26,6 \mathrm{~g}$ recomendam para o transporte o uso de 50 a $66 \mathrm{mg} / \mathrm{L}$ para faixas de temperatura entre a 20 e $25^{\circ} \mathrm{C}$. Segundo Ross e Geddes (1979) a aplicação de $10 \mathrm{mg} / \mathrm{L}$ de benzocaína na temperatura de $25^{\circ} \mathrm{C}$, é suficiente para levar a tilápia com peso de 5 a $50 \mathrm{~g}$ e o bagre do canal de 5 a $10 \mathrm{~g}$ a um estado de sedação profunda (aumento nos batimentos operculares), nivel de sedação desejado 
para o transporte (Ferreira et al., 1984). A mesma recomendação foi apresentada por Kubitza (1999).

\subsubsection{Jejum antes do transporte}

\subsubsection{Jejum e a resposta ao estresse do transporte}

Um dos requisitos básicos para manejar e transportar os peixes é que os mesmos estejam em bom estado de saúde e em boas condições antes de serem separados e embalados. O transporte de peixes vivos é reconhecido como uma das técnicas de manejo mais estressantes dentro da produção.

Segundo Kubitza (1999), peixes em jejum apresentam maior velocidade de recuperação do estresse decorrente do manejo da despesca, carregamento e transporte. Bocek (1996) reforça esta idéia quando afirma que peixes em jejum apresentam maior taxa de sobrevivência após o transporte. Pode-se afirmar a existência de uma relação direta entre o grau de repleção alimentar e a resposta do organismo animal às situações de estresse.

Mediante o estímulo de um fator estressante, o organismo animal responde rapidamente com uma série de reações metabólicas descritas como "Síndrome de Adaptação Geral", conforme apresentado por Mazeaud et al. (1977), Carmichael et al. (1984a) e Stickney (1986). A resposta fisiológica ao estresse é semelhante em peixes que sofreram privação alimentar ou peixes alimentados. Entretanto, a intensidade da resposta a este estímulo é distinta para os diferentes graus de repleção alimentar. Barton et al. (1988) em seu estudo sobre o efeito do grau de repleção alimentar na resposta de alevinos de "chinook salmon" ao estresse observaram aumentos nos niveis de cortisol e de glucose sanguíneo tanto para grupos de peixes com o trato digestivo vazio como com alimento. Os niveis de cortisol sanguineo atingidos foram semelhantes em ambos os grupo. No entanto, a hiperglicemia foi menor em peixes submetidos ao jejum. 
Farbridge e Leatherland (1992) obtiveram resultado semelhantes com trutas arco-íris alimentadas ou em jejum, após submissão ao estresse. De maneira geral, o incremento de cortisol no sangue após o estímulo do estresse ocorreu tanto para peixes submetidos ao jejum como para peixes alimentados, ocorrendo um decréscimo após 4 horas do estímulo. Entretanto, o nivel de cortisol voltou a crescer para peixes em jejum após 8 e 24 horas do estímulo, chegando a superar os niveis apresentados por peixes alimentados. Em contrapartida, Vijayan e Moon (1992) não observaram diferenças nos niveis de cortisol do sangue em juvenis de trutas arco-íris antes e depois de uma condição de estresse.

Quando submetido ao jejum ou a um longo período de privação alimentar, o organismo animal responde com uma redução na taxa metabólica e no uso de proteina, concomitantemente ocorre um o aumento na oxidação de gordura, na gluconeogênese e na formação de corpos cetônicos para suprir a demanda de energia dos tecidos dependentes de glucose (Castellini e Rea, 1992).

Méndez e Wieser (1993) observaram redução drástica nos niveis de glicogênio do sangue de Rutilus rutilus em crescimento após um período de privação alimentar. Mehner e Wieser (1994) não só constataram uma redução nos níveis de glicogênio no fígado e no músculo em alevinos de perca (Perca fluviatilis), como também verificaram a presença de alterações na concentração de proteína da carcaça para peixes privados de alimento.

Sheridan e Mommsen (1991) citados por Vijayan and Moon (1992) afirmam que o estado nutricional afeta diretamente o metabolismo de glicogênio em teleósteos. Aldrin et al. (1979) citados por Barton et al. (1988) explica que o grau de hiperglicemia após o estresse está diretamente relacionado com os niveis de glicogênio no figado. Deste modo, em situações de privação alimentar quando as reservas de glicogênio no fígado dos peixes foram quase que completamente mobilizadas para a manutenção do organismo animal, não há disponibilidade de glicogênio para atender a necessidade de aumento na glicemia do sangue no momento da resposta ao estresse secundário. Isto faz 
com que peixes submetidos ao jejum antes do manejo estejam menos aptos a trazer a tona uma forte resposta ao estresse, no que diz respeito à elevação nos níveis de glucose no sangue (Barton et al., 1988). 
Capítulo 3. Transporte de alevinos de tilápia do Nilo (Oreochromis niloticus) em sacos plásticos. I - Estudo comparativo dos parâmetros de qualidade da água do transporte em função do grau de repleção alimentar.

Alexsandra Carmen Caseiro ${ }^{1}$, José Eurico Possebon Cyrino ${ }^{1}$ e Fernado Kubitza ${ }^{2}$

1. Departamento de Produção Animal ESALQ-USP

Avenida Pádua Dias, 11 - Caixa Postal 11

13418-900 Piracicaba SP

2. Acqua \& Imagem Serviços

Jundiai - SP

\section{Resumo}

Com o objetivo de avaliar as variações nos parâmetros de qualidade da água durante o transporte de peixes vivos, alevinos de tilápia do Nilo, com peso médio entre 4,5 a $6,0 \mathrm{~g}$, submetidos ou não ao jejum de 48 horas, foram estocados na carga de $175 \mathrm{~g}$ de peixe/L em embalagens plásticas contendo $1,5 \mathrm{~L}$ de água (sem cloro e com $3 \mathrm{~g}$ de sal/L). Após os peixes terem sido estocados, as embalagens foram preenchidas com oxigênio até a marca de 8L. Os níveis de oxigênio dissolvido (OD), $\mathrm{pH}$, temperatura, amônia total $\left(\mathrm{NH}_{3 \text { total }}\right)$, amônia tóxica $\left(\mathrm{NH}_{3}\right)$ e gás carbônico $\left(\mathrm{CO}_{2}\right)$ foram registrados às $4,8,12,16 \mathrm{e}$ 20 horas após o início do bioensaio. Diferenças significativas entre os tratamentos com peixes alimentados e peixes em jejum foram observadas para os parâmetros $\mathrm{OD}, \mathrm{CO}_{2}, \mathrm{pH}, \mathrm{NH}_{3}$ total $\mathrm{e} \mathrm{NH}_{3}(\mathrm{P}<0,05)$. Estas diferenças 
persistiram para o tratamento tempo de transporte $(P<0,05)$. Interação significativa entre o tempo de transporte e a condição dos peixes foi registrada para todos os parâmetros de qualidade de água monitorados $(P<0,05)$. Embalagens contendo peixes alimentados apresentaram consumo mais acelerado de $\mathrm{OD}$ e maior concentração de $\mathrm{CO}_{2}$ e de $\mathrm{NH}_{3}$ total comparadas àquelas contendo peixes submetidos ao jejum $(P<0,05)$. Uma grande variação nos níveis de $\mathrm{NH}_{3}$, temperatura e $\mathrm{pH}$ foi observada para embalagens contendo peixes em jejum.

\begin{abstract}
Water quality was evaluated during live transportation of 4.5 to $6.0 \mathrm{~g}$ Nile tilapia fingerlings, non-fasted or fasted for 48 hour previous to transportation. Fish were stocked at a rate of $175 \mathrm{~g}$ of fish/L in plastic bags containing $1,5 \mathrm{~L}$ of water. After fish were stocked, the bags were filled with oxygen to a volume of $8 \mathrm{~L}$. Dissolved oxygen (DO), $\mathrm{pH}$, temperature, total ammonia nitrogen $\left(\mathrm{NH}_{3}\right.$ total $)$, unionized ammonia nitrogen $\left(\mathrm{NH}_{3}\right)$ and carbon dioxide $\left(\mathrm{CO}_{2}\right)$ were monitored at $4,8,12$, 16 and 20 hours from the beginning of the experiment. Significant differences were observed for $\mathrm{DO}, \mathrm{CO}_{2}, \mathrm{pH}, \mathrm{NH}_{3 \text { total }}$ and $\mathrm{NH}_{3}(\mathrm{P}<0.05)$ between treatments with non-fasted or fasted fish. Such differences were maintained along the time $(P<0.05)$. There was a significant interaction between time of transport and fish condition for all the water quality parameters. Water with non-fasted fish had a faster decline in $\mathrm{OD}$ and accumulated more $\mathrm{CO}_{2}$ and $\mathrm{NH}_{3}$ tota compared to water with fasted fish. Water $\mathrm{NH}_{3}$, temperature and $\mathrm{pH}$ showed great variation in bags containing fasted fish.
\end{abstract}

\title{
Introdução
}

O jejum é uma prática preventiva recomendada para minimizar o estresse decorrente do manejo da despesca e do transporte (Frankfort, 1989). A 
velocidade de recuperação dos peixes ao estresse decorrente do manejo da despesca, carregamento e transporte. é maior quando estes são submetidos ao jejum (Kubitza, 1999). Bocek (1996) reforça esta idéia quando afirma que peixes em jejum apresentam maior taxa de sobrevivência após o transporte, 0 que sugere a existência de uma relação direta entre o grau de repleção alimentar e a resposta do organismo animal às situações de estresse.

A aplicação do jejum diminui o consumo de oxigênio, o acúmulo de material fecal e a excreção de metabolitos, prevenindo a rápida deterioração da qualidade da água nas embalagens e tanques de transporte (McCraren e Millard, 1978; Stickney, 1986; Frankfort, 1989, Swan, 1992 ).

Imediatamente após a ingestão dos alimentos, o organismo animal inicia a sua digestão, processo fisiológico que envolve as vias de absorção, excreção e crescimento. Durante o período de passagem do alimento pelo trato digestivo, verifica-se o aumento na taxa de consumo de oxigênio (Solomon e Taylor, 1979; Jobling, 1981) e na taxa de excreção de metabolitos (Gélineau et al., 1998). Lied e Bratton (1984) compararam o efeito do grau de repleção alimentar sobre a taxa de excreção de amônia e o consumo de oxigênio (OD) do bacalhau (Gadus morhua). Peixes em jejum apresentaram uma taxa de excreção amônia comparável àquela apresentada em condições de manutenção. Peixes previamente alimentados apresentaram maior excreção de amônia, e um aumento na demanda de OD com um pico de consumo registrado 9 a 10 horas após a alimentação. A excreção de amônia e o consumo de OD somente retornaram aos níveis iniciais 25 horas após a última alimentação.

Ross et al. (1992) citados por Ross (2000), observaram que tilápias alimentadas com ração contendo $29 \%$ de proteína apresentaram um aumento no consumo de oxigênio imediatamente após a alimentação, registrando-se um pico de consumo de 7 horas após a alimentação. Segundo os autores, aos níveis de consumo de oxigênio dos peixes somente retornaram às condições de manutenção após 16 horas do consumo do alimento. 
A importância do jejum é ainda maior quando o transporte é feito em sacos plásticos, uma vez que as quantidades de água e de oxigênio dissolvido disponível são limitadas. Adicionalmente, nestas condições, a realização de trocas parciais ou totais da água das embalagens para reduzir as concentração de metabolitos durante o transporte é uma prática inviável, visto que as embalagens, na grande maioria das vezes, são enviadas via serviço aéreo ou terrestre. Mesmo reconhecendo a importância da aplicação do jejum antes do transporte, muitos piscicultores negligenciam esta prática.

O presente estudo objetivou a avaliação dos parâmetros de qualidade de água durante o transporte de alevinos de tilápia alimentadas ou em jejum, durante diferentes tempos de transporte.

\section{Material e métodos}

\section{Peixes e unidades experimentais}

Alevinos de tilápia do Nilo (Oreochromis niloticus) com peso médio em torno de 4,5 a 6,0 $\mathrm{g}$ foram submetidos a uma simulação de transporte em sacos plásticos. As embalagens foram preparadas com sacos de polietileno transparente com $0,2 \mathrm{~mm}$ de espessura, medindo $30 \times 60 \mathrm{~cm}$. O volume útil utilizado das embalagens foi de $8 \mathrm{~L}$, sendo que cada embalagem recebeu 1,5 litros de água (sem cloro e com $3 \mathrm{~g}$ de sal/litro) com a seguinte qualidade inicial: $\mathrm{OD}=7,0 \mathrm{mg} / \mathrm{L} ; \mathrm{CO}_{2}=6,0 \mathrm{mg} / \mathrm{L} ; \mathrm{pH}=7,5 ;$ Temperatura $=25,6^{\circ} \mathrm{C} ; \mathrm{NH}_{3 \text { total }}=$ $0,4 \mathrm{mg} / \mathrm{L} ; \mathrm{NH}_{3}=0,002 \mathrm{mg} / \mathrm{L} ;$ Alcalinidade total $=38 \mathrm{mg} / \mathrm{L}$ e Dureza $=96 \mathrm{mg} / \mathrm{L}$.

Após a estocagem dos peixes todo o ar das embalagens foi removido, e as mesmas preenchidas com oxigênio comprimido até a marca de 8 litros. Os sacos foram vedados com tiras de borracha e colocadas em caixas de papelão, para impedir a entrada de luz e a influência da temperatura ambiente.

Cinqüenta peixes foram estocados por embalagem, o que representou uma carga ao redor de $175 \mathrm{~g} / \mathrm{L}$. Metade das embalagens foram preparadas com peixes submetidos ao jejum de 48 horas e a outra com peixes sem jejum. Os 
parâmetros de qualidade da água ( $\mathrm{OD}, \mathrm{CO}_{2}, \mathrm{pH}$, temperatura, $\mathrm{NH}_{3 \text { total }} \mathrm{e} \mathrm{NH}_{3}$ ), bem como o comportamento dos peixes nas embalagens foram avaliados em 3 embalagens de cada carga e estado de repleção alimentar, às 4, 8, 12, 16, 20 e 24 horas de transporte. A sobrevivência dos peixes também foi avaliada durante até 24 horas após o término da avaliação. Ao todo, foram preparadas 30 embalagens. Para monitorar os parâmetros de qualidade da água foram utilizados os seguintes equipamentos: medidor de oxigênio YSI Modelo 55 (OD e temperatura), medidor de $\mathrm{pH}$ portátil Hanna $(\mathrm{pH})$, e kit de análise de água Hach modelo FF2 $\left(\mathrm{NH}_{3 \text { total }}, \mathrm{NH}_{3}, \mathrm{CO}_{2}\right.$, Alcalinidade e Dureza).

\section{Delineamento experimental e análises estatísticas}

O bioensaio foi constituído de 10 tratamentos e 3 repetições, perfazendo um delineamento experimental inteiramente ao acaso. Os tratamentos foram estabelecidos em um arranjo fatorial, onde foram comparados 2 graus de repleção alimentar (jejum de 48 horas vs peixe alimentado) em função dos tempos de transporte $(4,8,12,16$ e 20 horas). Os dados coletados foram analisados através do sistema de análise estatistica SAS, com uso das ferramentas PROC REG (análise da variância e análise de regressão) e PROC CORR (análise de correlação de Spearman).

\section{Resultados}

O grau de repleção alimentar e o tempo de transporte exerceram forte influência nos parâmetros de qualidade da água. Isto expressa a ocorrência de diferença significativa nos niveis de $\mathrm{OD}, \mathrm{CO}_{2}, \mathrm{pH}$, temperatura, $\mathrm{NH}_{3 \text { total }}$ e $\mathrm{NH}_{3}$ $(P<0,05)$ no que diz respeito ao estado alimentar e tempo considerados como fatores isolados.

O oxigênio dissolvido na água não apresentou variação ao longo do transporte. No entanto, os niveis de OD permaneceram sempre mais elevados 
nas embalagens com peixes submetidos ao jejum de 48 horas prévio ao transporte (Figura 1). Ao final de 20 horas de experimento, o nível médio de OD na água foi de $12 \mathrm{mg} / \mathrm{L}$ em embalagens com peixes em jejum e $9 \mathrm{mg} / \mathrm{L}$ no transporte de peixes alimentados $(P<0,05)$.

A concentração de $\mathrm{CO}_{2}$ na água aumentou do nivel inicial de $6 \mathrm{mg} / \mathrm{L}$ para valores médios de $306 \mathrm{mg} / \mathrm{L}$ após 20 horas de transporte de peixes alimentados. Este valor foi $81 \%$ superior aos $169 \mathrm{mg} / \mathrm{L}$ registrados no transporte de peixes em jejum (Figura 2).

No transporte de peixes alimentados, $\mathrm{opH}$ da água apresentou uma súbita redução de 7,5 para 6,0 nas primeiras 4 horas do transporte, estabilizando-se neste valor até o final do experimento (Figura 4). Já no transporte de peixes em jejum o $\mathrm{pH}$ da água apresentou declínio constante de 7,5 a 6,0 do início até 20 horas do transporte $(P<0,05)$.

A concentração média de $\mathrm{NH}_{3}$ total na água (Figura 5) aumentou linearmente ao longo do transporte, atingindo niveis de $132 \mathrm{mg} / \mathrm{L}$ para os peixes alimentados após 20 horas de transporte. Este valor foi $59 \%$ superior aos $83 \mathrm{mg} / \mathrm{L}$ registrados na água de transporte dos peixes submetidos ao jejum para a mesma duração do transporte $(P<0,05)$. Embora tenham sido observados elevados niveis de $\mathrm{NH}_{3}$ total, a concentração de amônia tóxica $\left(\mathrm{NH}_{3}\right)$ não excedeu a $0,10 \mathrm{mg} / \mathrm{L}$ durante todo o experimento e declinou para valores médios de 0,046 e $0,074 \mathrm{mg} / \mathrm{L}$ após 20 horas, no transporte de peixes em jejum e alimentados, respectivamente (Figura 6).

A taxa de excreção de amônia foi crescente ao longo do tempo de transporte para ambos os grupos de peixes $(P<0,05)$. No entanto, a taxa de excreção de $\mathrm{CO}_{2}$ foi influenciada pelo estado de repleção dos peixes. A taxa de excreção de $\mathrm{CO}_{2}$ foi crescente até as 16 horas de transporte de peixes em jejum, apresentando declínio nas últimas 4 horas. Já para os peixes alimentados, a maior taxa de excreção de $\mathrm{CO}_{2}$ foi observada nas primeiras 4 horas de transporte, seguida de um progressivo declínio até $\bigcirc$ final do experimento (Figura 7). 


\section{Discussão}

\section{Oxigênio dissolvido}

O grau de repleção alimentar afeta a taxa de consumo de oxigênio (HillerAdams e Childress, 1983 citados por Yang e Somero, 1993). No presente estudo, a submissão dos alevinos de tilápia a um jejum de 48 horas resultou em menor consumo de oxigênio durante o transporte. Nas primeiras 4 horas de transporte o OD foi $80 \%$ maior nas embalagens com peixes em jejum.

Méllard (1986) citado Kubitza (2000) observou que tilápias do Nilo alimentadas apresentaram consumo de oxigênio duas vezes superior ao consumo de manutenção. Ross (2000) registrou para a tilápia do Nilo um consumo de oxigênio de até 1,7 vezes maior para peixes alimentados comparados com peixes em jejum. Dependendo do nivel de alimentação, está diferença pode chegar até 2,3 vezes, mantendo-se elevada entre 12 e 24 horas após a alimentação, somente retornando ao consumo de manutenção 36 a 42 horas após o fornecimento de alimento.

Jobling (1981) afirma que peixes alimentados apresentam maior demanda de oxigênio, e em algumas situações chegam a consumir o dobro do oxigênio necessário para a manutenção. Mehner e Wieser (1994) observaram o mesmo efeito com alevinos de perca comum (Perca fluviatus) e sugeriram que a redução na taxa de consumo de OD de peixes submetidos a um jejum de 48 horas estava relacionada a uma redução no gasto de energia apresentada na fase de transição pela qual passam os animais submetidos à privação alimentar. A fase de transição é fortemente marcada pela redução no consumo de oxigênio (Méndez e Wieser, 1993).

Após 20 horas de transporte, foi observado um nivel de OD $33 \%$ superior na água das embalagens com tilápias em jejum. De forma similar, Wieser et al. (1992) citados por Méndez e Wieser (1993), observaram um consumo de 
oxigênio 30 a $40 \%$ menor para juvenis de Rutilus rutilus submetidos ao jejum de 48 horas.

\section{Metabolitos nitrogenados e gás carbônico}

No presente estudo, após 20 horas de transporte, os niveis de $\mathrm{CO}_{2}$ e $\mathrm{NH}_{3}$ total observados nas embalagens com peixes alimentados foram, respectivamente, 133 e $60 \%$ superiores aos apresentados nas embalagens contendo peixes em jejum de 48 horas.

O diferencial apresentado para os níveis de $\mathrm{CO}_{2}$ entre os sacos plásticos contendo peixes em jejum e peixes alimentados pode ser explicado pelo aumento da taxa respiratória dos peixes alimentados. Após a ingestão do alimento, o organismo animal desencadeia uma série de reações metabólicas para fornecer a energia necessária para a digestão, absorção, metabolismo e excreção dos nutrientes dos alimentos (Jobling, 1981). O ritmo respiratório é aumentado, tendo como resposta um aumento no consumo de oxigênio e na excreção de $\mathrm{CO}_{2}$. Peixes alimentados apresentam o dobro de consumo de oxigênio quando comparados com peixes mantidos em jejum (Jobling, 1981; Yang e Somero, 1993, Ross, 2000) e, consequentemente, excretam mais ou menos na mesma proporção (Randall, 1984).

As concentrações de $\mathrm{NH}_{3 \text { total }}$ na água do transporte reforçam o conceito apresentado por Wood (1995) citado por Lintin et al. (1997) de que a alimentação é o fator de maior importância sobre a taxa de excreção de metabolitos nitrogenados. Após as proteinas ingeridas terem sido hidrolisadas no trato gastro-intestinal ocorrerá a absorção dos aminoácidos nitrogenados através da mucosa do intestino. No fígado, os aminoácidos são fixados apenas em parte pelas células hepáticas indo o restante para a corrente sangüinea, o qual forma um "pool" de aminoácidos do qual o organismo se serve em função das suas necessidades (Andriguetto et al., 1994). Peixes alimentados mantém 
um "pool" maior de aminoácidos circulantes no sangue, comparados aos peixes em jejum, o que aumenta o potencial de excreção de $\mathrm{NH}_{3}$ total.

Embora a taxa de excreção de amônia tenha sido crescente durante as 20 horas de transporte, a taxa de excreção de $\mathrm{CO}_{2}$ nas embalagens com peixes alimentados foi máxima nas primeiras 4 horas de transporte $(116 \mathrm{mg} / \mathrm{kg} / \mathrm{hora})$, com os niveis médios de $\mathrm{CO}_{2}$ da água atingindo $128 \mathrm{mg} / \mathrm{L}$. Deste ponto ao final do experimento a taxa de excreção de $\mathrm{CO}_{2}$ declinou. Por outro lado, nas embalagens com peixes em jejum a taxa de excreção de $\mathrm{CO}_{2}$ foi crescente até as 16 horas de transporte $(155 \mathrm{mg} / \mathrm{kg} / \mathrm{hora})$, com a água atingindo uma concentração média de $169 \mathrm{mg}$ de $\mathrm{CO}_{2} / \mathrm{L}$. Só a partir deste ponto foi observada uma redução na taxa de excreção de $\mathrm{CO}_{2}$. As concentrações de $\mathrm{CO}_{2}$ observadas na água do transporte das embalagens contendo peixes alimentados (4 horas) e peixes em jejum (16 horas), vão de encontro ao sugerido por Gilderhus e Marking (1987) como níveis anestésicos para alevinos, ao redor de 120 a $150 \mathrm{mg}$ de $\mathrm{CO}_{2} / \mathrm{L}$.

A elevada concentração de $\mathrm{CO}_{2}$ na água pode levar a uma redução na atividade metabólica dos peixes. Este fato está associado à redução na atividade do cérebro, ocasionada pelo decréscimo no $\mathrm{pH}$ do cérebro acarretado pelo efeito do $\mathrm{CO}_{2}$ no organismo animal (Sinohara, 1987 citado por Yoshikawa et al., 1991).

A taxa de excreção de $\mathrm{NH}_{3}$ total para peixes em jejum ou alimentados foi crescente durante todo o transporte. Forsberg (1997) cita que a excreção de nitrogênio é subdividida em excreção endógena e excreção exógena. A excreção endógena reflete o catabolismo e o "turnover" das proteinas do corpo e independe do estado alimentar do animal. Já a excreção exógena se relaciona ao catabolismo das proteínas originadas do alimento ingerido, sendo portanto influenciada pelo grau de repleção alimentar do animal. Com base neste conceito, a taxa crescente de excreção de $\mathrm{NH}_{3}$ total em tilápias submetidas ao jejum pode ser atribuída a excreção endógena. A diferença na taxa de 
excreção observada entre peixes alimentados e peixes em jejum pode ser atribuída ao metabolismo exógeno da amônia.

Diferente do que era esperado, a taxa de excreção de amônia não seguiu a mesma tendência apresentada na excreção do $\mathrm{CO}_{2}$. O conceito que pode explicar este diferencial é apresentado por Wright et al. (1989) citados Mommsen e Walsh (1992), que enfatizam que excreção de $\mathrm{CO}_{2}$ acidifica a camada de água em torno das brânquias, seguindo de uma efetiva remoção de amônia através da protonação do ion amônio. Wood (1985) citados por Randall e Wright (1989) explicam que sob condições de acidez extrema, a taxa de excreção de amônia pode ser reduzida devido a inibição na troca do ion $\mathrm{Na}^{+}$ pelo ion $\mathrm{NH}_{4}{ }^{+}$. Entretanto, sob condições de ambiente medianamente ácidas ( $\mathrm{pH}$ da água $=6,64)$, a taxa de excreção se mantém ou pode aumentar, uma vez que o nível de acidez não interfere na troca de cátions através do epitélio branquial (Wright e Wood, 1985 citados por Randall e Wright, 1989).

\section{Temperatura da água}

Grande variação nas leituras da temperatura da água foi observada ao longo do tempo de transporte. Acredita-se que esta variação seja decorrente das variações na temperatura ambiental, devido ao reduzido volume de água nas embalagens usadas. Não foi possivel relacionar a variação de temperatura observada ao grau de repleção alimentar dos peixes. No início do ensaio, às 10:00 AM, a temperatura era de $25,7^{\circ} \mathrm{C}$ e no final do ensaio, às 4:00 AM do dia seguinte era de $25,0^{\circ} \mathrm{C}$. Entretanto, ao longo do ensaio foi possivel observar um máximo de temperatura da água de transporte de $27,5^{\circ} \mathrm{C}$ para embalagens com peixes alimentados. 


\section{Conclusões}

Embora não tenha sido notado efeito do jejum na sobrevivência dos peixes durante e após o transporte, em algumas ocasiões é possivel que a manutenção de uma água de melhor qualidade e menor carga fecal possa reduzir a incidência de doenças e mortalidade dos alevinos pós-transporte. A submissão dos peixes ao jejum proporcionou melhores niveis de OD, menor concentração de $\mathrm{CO}_{2}$, menor concentração de $\mathrm{NH}_{3}$ total e de $\mathrm{NH}_{3}$ ao final das 20 horas de transporte, diminuindo a intensidade do estresse de transporte sobre os peixes.

\section{Agradecimentos}

Agradecemos à Piscicultura Paulista - Piracicaba, SP por ter cedido os alevinos de tilápia do Nilo para a execução deste bioensaio.

\section{Referências bibliográficas}

ANDRIGUETTO, J. M.; L. PERLY, I. MAINARDI, A GEMAEL, J. S. FLEMMING,

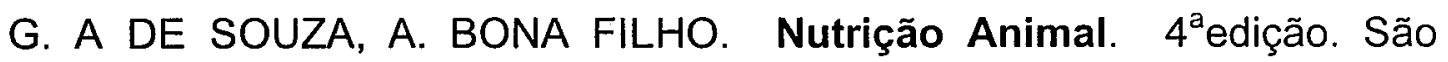
Paulo: Nobel. 1996, v. 11, 394p.

BOCEK, A. Transporting fish. Auburn: Auburn Universtity. International Center for Aquaculture and Aquatic Environments, 1996. 16p.

FORSBERG, O. I. The impact of varying feeding regimes on oxygen consumption and excretion of carbon dioxide and nitrogen in post-smolt Atlantic salmon Salmo salar L. Aquaculture-Research, v. 28, n. 1, p. 2941, 1997.

FRANKFORT, K. Here are some tips for transporting fish safetely. Water Farming Journal. March, 1989, p.13. 
GÉliNEAU, A; MEDALE, F; BOUJARD, T. Effect of feeding time on postprandial nitrogen excretion and energy expenditure in rainbow trout. Journal of Fish Biology. v. 52, n. 4, p. 655-664, 1998.

GILDERHUS, P. A.; MARKING, P. A. Comparative efficacy of 16 anesthetic chemicals on rainbow trout. North American Journal of Fisheries Management, v. 7, p. 288-292, 1987.

JOBLING, M. The influences of feeding on the metabolic rate of fishes: a short review. Journal of Fish Biology. v.18, p. 385-400, 1981.

KUBITZA, F. Técnicas de transporte de peixes. $3^{a}$ edição, Jundiaí: $F$. Kubitza, 1999. 51p.

KUBITZA, F. Tecnologia e planejamento na produção de tilápia. Jundiaí: $F$. Kubitza. 289p., 2000.

LIED, E.; BRATTON, B. The effect of feeding and starving, and different ratios of protein energy to total energy in feed excretion of amonia in Atlantic Cod (Gadus morhua). Comparative Biochemistry and Physiology, v. 78b, p. 49-52, 1984.

LINTIN, T. K; S. D. REID; C. M. WOOD. The metabolic costs and physiological consequences to juvenile rainbow trout of a simulated summer warming scenario in the presence and absence of sublethal ammonia. Transactions of the American Fisheries Society, v. 126, p. 259-272, 1997.

MCCRAREN, J. P.; J. L. MILLARD. Manual of fish culture. Section G: Fish transportation. San Marcos: US Fish and Wildlife Service. 1978. p. 44-88: Transportation of warmwater fishes.

MEHNER, T.; WIESER, W. Energetics and metabolic correlates of starvation in juvenile perch (Perca fluviatilis). Journal of Fish Biology. v. 45, n. 2, p. 325-333, 1994. 
MÉNDEZ, G.; WEISER,W. Metabolic responses to food deprivation and refeeding in juveniles of Rutilus rutilus (Teleostei: Cyprinidae). Environmental Biology of Fishes. v. 36, n. 1, p. 73-81, 1993.

MOMMSEN, T. P.; WALSH, P. J. Biochemical and environmental perspectives on nitrogen metabolism in fishes. Experientia, v. 48, p. 583-593, 1992.

RANDALL, D. Gas exchange in fish. In: HOAR, W. S.; RANDALL, D. J.(ed) Fish Physiology. Orlando: Academic Press, 1984, v. X, cap. 7, p. 253$292 p$.

RANDALL, D; WRIGHT, P. A. The interaction between carbon dioxide and ammonia excretion and water $\mathrm{pH}$ in fish. Canadian Journal of Zoology, $\mathrm{v}$. 67 , p. 2936-2942, 1989.

ROSS, L. G. Environmental physiology and energetics. In: Beveridge, M. C. M; McAndrew, B. J. (ed). Tilapias: biology and exploitation. Dordrecht: Kluer Academic Publishers. v. 25, p. 89-128, 2000.

SOLOMON, D. J. ; L. TAYLOR. Critical factors in the transport of live freshwater fish - II State of feeding and ammonia excretion. Fish Management. v. 10, n. 2, p. 81-85, 1979.

STICKNEY, R. R. Culture of nonsalmonid freshwater fishes. Washington: University of Washington. 1986. p. 74 - 89: Centrarchids.

SWAN, L. Transportation of fish in bags. North Central Regional Aquaculture Center, Fact Sheet Series \#104, 4p. November, 1992.

YANG, T. H.; SOMERO, G. N. Effects of feeding and food deprivation on oxygen consumption, muscle protein concentration and activities of energy metabolism enzymes in muscle and brain of shallow-living (Scorpaena guttata) and deep-living (Sebastolobus alascanus) Scorpaenid fishes. Journal of Experimental Biology. v. 181, p. 213-232, 1993.

YOSHIKAWA, H.; Y. YOKOYAMA, Y.; UENA, S.; MITSUDA, $H$. Changes of blood gas in carp, Cyprinus carpio, anesthetized with carbon dioxide. Comparative Biochemistry and Physiology. v. 98A, n. 3/4, p. 431-436, 1991. 
Anexos A 


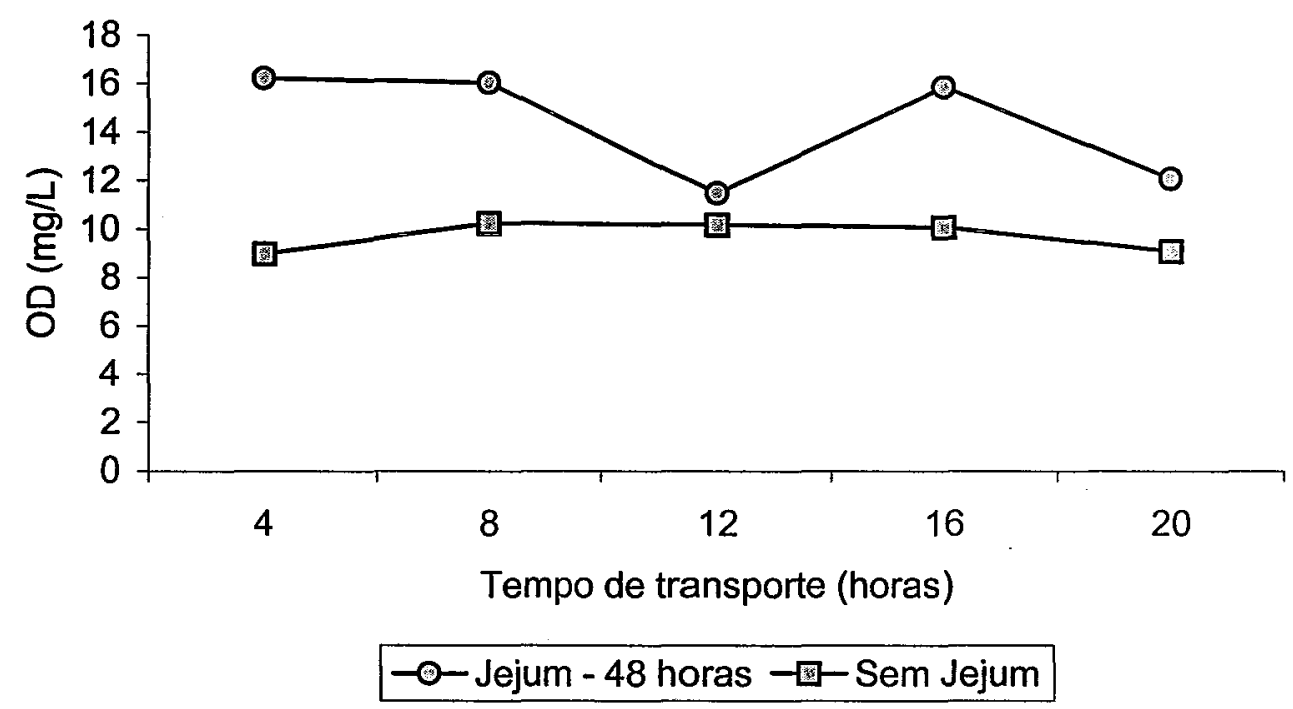

Figura 1. Variação nos niveis de oxigênio dissolvido na água do transporte em sacos plásticos com peixes sem jejum ou em jejum de 48 horas.

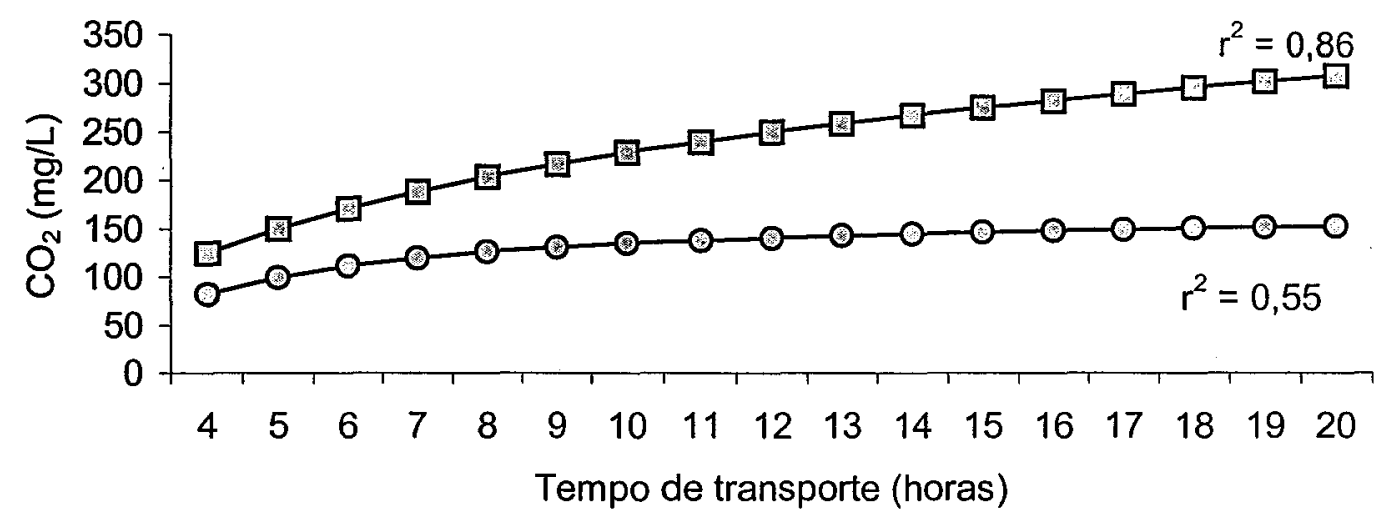

-O-Jejum - 48 horas - - - Sem Jejum

Figura 2. Variação nos níveis de $\mathrm{CO}_{2}$ na água do transporte em sacos plásticos com peixes sem jejum ou em jejum de 48 horas.

1. Jejum de 48 horas: $\mathrm{CO}_{2}=6,5118-0,00139$ tempo ${ }^{2}$

2. Sem Jejum: $\mathrm{CO}_{2}=-33,8025+114,0612$ Intempo 


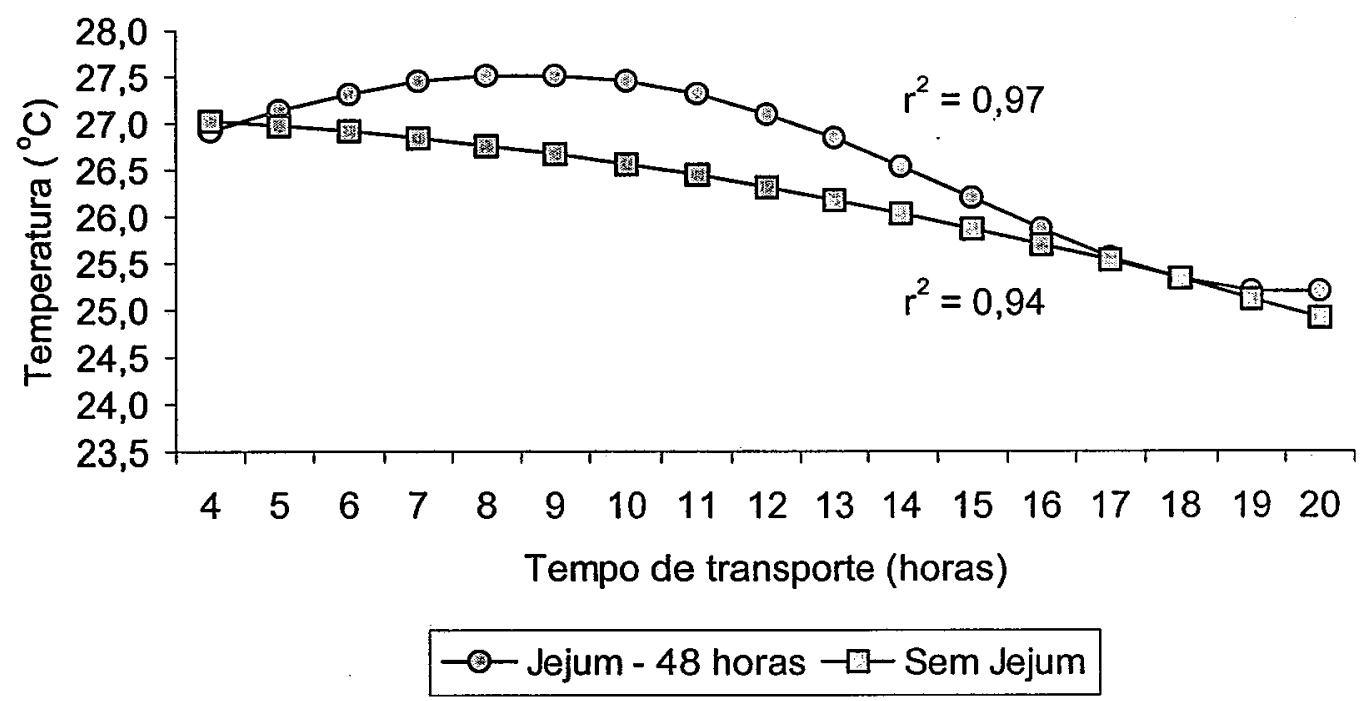

Figura 3. Variação na temperatura da água do transporte ao longo do tempo para sacos plásticos com peixes sem jejum ou em jejum de 48 horas.

1. Jejum de 48 horas:

Temperatura $=24,9785+0,0908$ tempo $^{2}-0,0095$ tempo $^{3}+0,00025$ tempo $^{4}+4,1837$ (1/tempo)

2. Sem Jejum: Temperatura $=27,1096-0,0055$ tempo $^{2}$

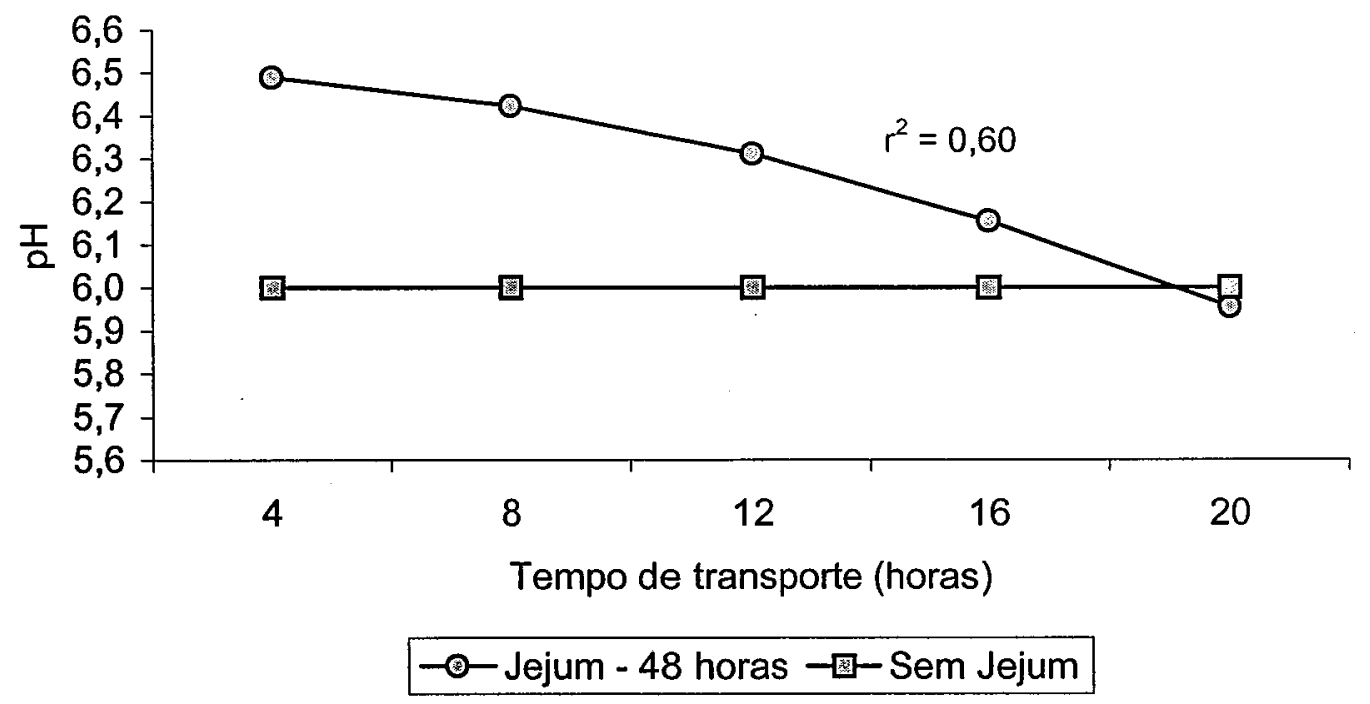

Figura 4. Variação nos níveis de pH ao longo do tempo de transporte em sacos plásticos com peixes sem jejum ou em jejum de 48 horas.

1. Jejum de 48 horas: $\mathrm{pH}=6,5118-0,00139$ tempo $^{2}$

2. Sem jejum: $\mathrm{pH}=$ valores médios 


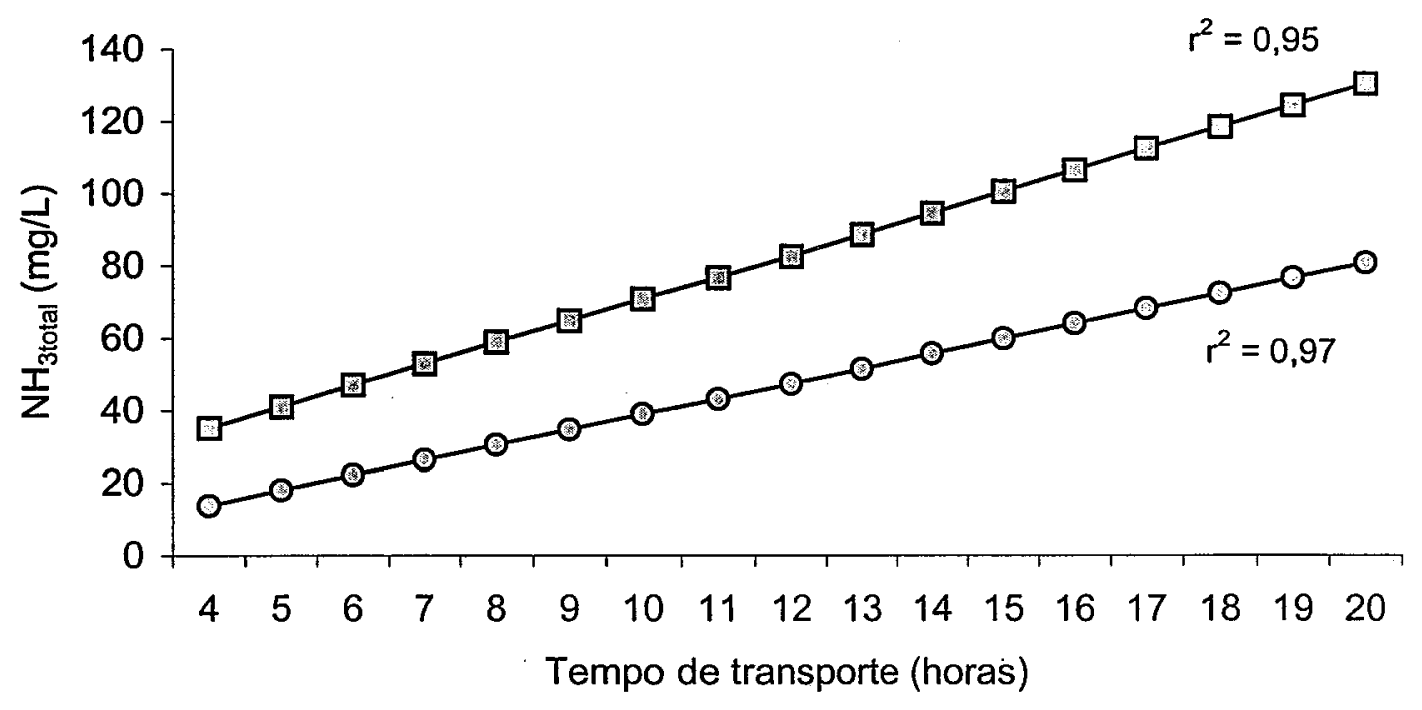

-๑-Jejum - 48 horas - - -Peixe Alimentado

Figura 5. Variação nos niveis de amônia total na água do transporte em sacos plásticos com peixes sem jejum ou em jejum de 48 horas.

1. Jejum 48 horas: $\mathrm{NH}_{3 \text { total }}=-2,9467+4,1834$ tempo

2. Peixe alimentado: $\mathrm{NH}_{3 \text { total }}=11,36+5,94$ tempo

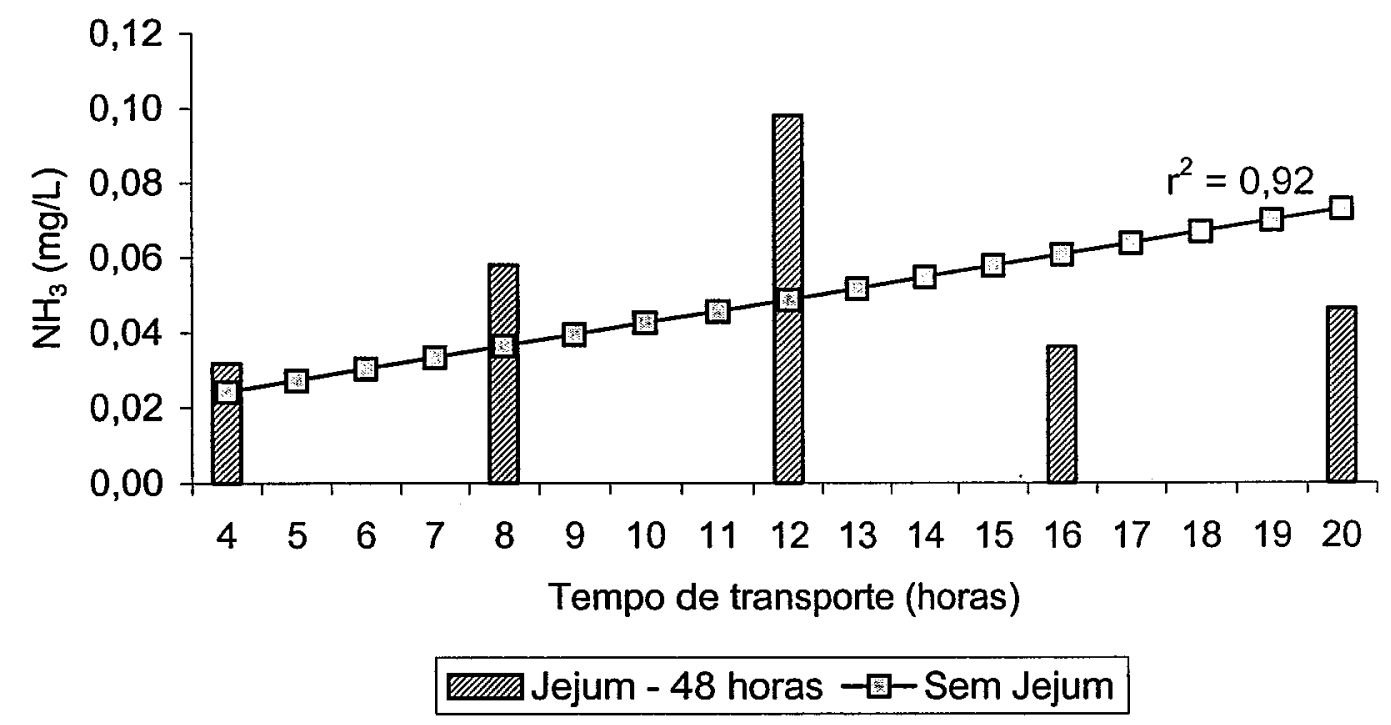

Figura 6. Variação nos níveis de amônia tóxica na água do transporte em sacos plásticos com peixes sem jejum ou em jejum de 48 horas.

1. Jejum 48 horas: $\mathrm{NH}_{3}=$ valores médios

2. Peixe alimentado: $\mathrm{NH}_{3}=0,012+0,00305$ tempo 


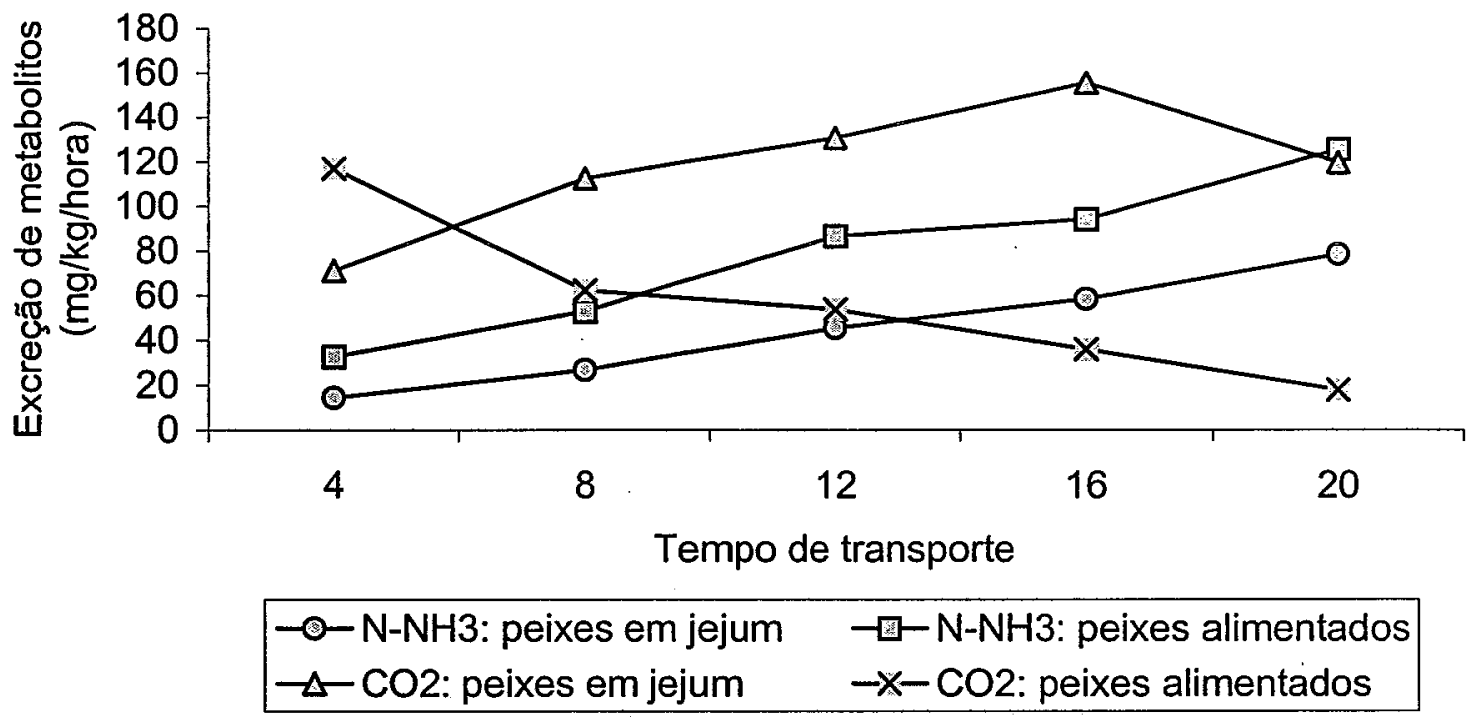

Figura 7. Variação na taxa de excreção de metabolitos durante o transporte de alevinos em sacos plásticos para os intervalos de tempo onde foram tomadas as medições da qualidade da água. 


\section{Capítulo 4. Transporte de alevinos de tilápia do Nilo (Oreochromis}

niloticus) em sacos plásticos. II - Estudo comparativo do uso de doses de benzocaína (aminobenzoato etílico) interferindo nas cargas de transporte e nos parâmetros de qualidade da água.

Alexsandra Carmen Caseiro ${ }^{1}$, José Eurico Possebon Cyrino ${ }^{1}$ e Fernado Kubitza ${ }^{2}$

1. Departamento de Produção Animal ESALQ-USP

Avenida Pádua Dias, 11 - Caixa Postal 11

13418-900 Piracicaba SP

2. Acqua \& Imagem Serviços

Jundiai - SP

\section{Resumo}

Alevinos de tilápia do Nilo (O. niloticus) com 4,4 a 5,0 g submetidos a um período de jejum de 72 horas foram utilizados para a avaliação do efeito do uso do anestésico aminobenzoato etílico (benzocaína) no transporte de peixes vivos em sacos plásticos. Para a avaliação foram testadas três doses de benzocaína $(0,10$ e $20 \mathrm{mg} / \mathrm{L}$ ) e duas cargas de transporte (235 e $470 \mathrm{~g} / \mathrm{L})$, perfazendo um experimento fatorial $3 \times 2$. O estudo avaliou variações no tempo de transporte entre os tratamentos, níveis finais de oxigênio dissolvido (OD), gás carbônico $\left(\mathrm{CO}_{2}\right)$, nitrogênio amoniacal total $\left(\mathrm{NH}_{3 \text { total }}\right)$, amônia não ionizada $\left(\mathrm{NH}_{3}\right), \mathrm{pH}$ e temperatura da água. Os peixes foram estocados em sacos de polietileno transparente, contendo $1,5 \mathrm{~L}$ de água (sem cloro e com a adição de $3 \mathrm{~g}$ de sal/litro). Após a estocagem dos peixes, as embalagens foram preenchidas com 
oxigênio até o volume de $8 \mathrm{~L}$. O estudo comparativo entre as cargas de transporte demonstrou a presença de diferença significativa para os parâmetros tempo de transporte, $\mathrm{OD}, \mathrm{CO}_{2}, \mathrm{NH}_{3 \text { total }}$ e $\mathrm{NH}_{3}(\mathrm{P}<0,05)$. No entanto, os efeitos da diferentes doses de benzocaína não foram significativos $(P>0,05)$, a não ser pela tendência de redução nos niveis de $\mathrm{NH}_{3}$ total na água do transporte com o aumento das doses de anestésico para a maior carga de peixe $(P<0,05)$. Os elevados niveis de $\mathrm{CO}_{2}$ na água do transporte $(131 \mathrm{mg} / \mathrm{L}$ para a menor, e $207 \mathrm{mg} / \mathrm{L}$ para a maior carga testada) pode ter exercido ação tranquilizante nos peixes, mascarando os efeitos do uso da benzocaína.

\section{Abstract}

The effects of benzocaine on the water quality were evaluated during live transportation of $5 \mathrm{~g}$ tilapia fingerlings in plastic bags. Fish were fasted 72 hours prior to the study and were loaded into $8-\mathrm{L}$ plastic bags at 235 or $470 \mathrm{~g}$ of fish per liter of water. Benzocaine were tested at 10 or $20 \mathrm{mg} / \mathrm{L}$. Control treatments without the use of benzocaine were set for both fish loads. The plastic bags were completed with oxygen right after the fish had been loaded. Water quality parameters such as dissolved oxygen, carbon dioxide, $\mathrm{pH}$, total ammonia nitrogen and unionized ammonia nitrogen were evaluated at the beggining of the experiment and at the time fish started to show respiratory distress. At this moment, the bags were opened and the water analysed. This time was recorded and compared among the treatments. Fish load significantly influenced the time fish started to show respiratory distress and the dissolved oxygen, carbon dioxide, total ammonia nitrogen and unionized ammonia nitrogen $(P<0,05)$. The use of benzocaine did not result in any improvement on the water quality, with the exception of the reduced total ammonia nitrogen concentration observed at the higher fish load $(P<0,05)$. It is possible that the high levels of carbon dioxide in the water $(131 \mathrm{mg} / \mathrm{L}$ for the lower, and $207 \mathrm{mg} / \mathrm{L}$ for the higher fish load) had an effective tranquilizing action on fish, masking the effects of using benzocaine. 


\section{Introdução}

O uso de anestésicos em piscicultura têm sido freqüente no manejo de reprodutores e durante o manuseio, pesagem e contagem de peixes. Nas operações envolvidas com o transporte de peixes, os anestésicos podem auxiliar na redução da agitação dos peixes, diminuindo a ocorrência de injúrias físicas durante o manuseio e carregamento, além de amenizar o estresse fisiológico nos peixes (Taylor e Salomon, 1979b, McFarland, 1959 citado por Ferreira et al., 1984).

Adicionalmente, os anestésicos contribuem para uma redução na taxa de consumo de oxigênio e na excreção de metabolitos (Piper et al., 1989; Jensen, 1990a), permitindo transportar maiores cargas de peixes com segurança e mínimo custo, notadamente no que diz respeito aos transporte de peixes a longas distâncias.

O uso de anestésicos acarreta uma série de alterações fisiológicas no organismo animal, o que exige atenção especial quanto às doses e tempo de administração, bem como a intensidade de sedação desejada. No transporte de peixes vivos o grau de sedação deve levar o peixe a uma redução na atividade, porém sem grandes perdas de equilíbrio, o que seria equivalente a um primeiro nível de anestesia, em sedação leve a profunda (aumento dos batimentos operculares, porém sem perda do equilibrio), conforme descrito por McFarland (1960) citado por Durve (1975).

Em um estudo avaliando a eficácia de 16 anestésicos em truta arco-íris em condições controladas, Gilderhus e Marking (1987) constataram que as 4 melhores substâncias foram a tricaina metano sulfonato (MS-222), a quinaldina, a benzocaina e o 2-phenoxyethanol. Dentre estas, os autores listam a benzocaína como a mais vantajosa por ser efetiva em menores concentrações e apresentar um custo $30 \%$ menor do que o MS-222, anestésico tradicionalmente mais usado em peixes. 
O presente trabalho foi conduzido com o objetivo de avaliar o benefício do uso da benzocaína no transporte de alevinos de tilápia, avaliando o seu efeito sobre o tempo de transporte para duas cargas de peixes e sobre os parâmetros de qualidade de água ao longo do transporte.

\section{Material e métodos}

\section{Peixes e unidades experimentais}

Neste estudo foram utilizados alevinos de tilápia do Nilo (O. niloticus) com 4,4 a $5,0 \mathrm{~g}$, submetidos a um jejum de 72 horas. Os peixes foram estocados em 18 sacos plásticos transparentes com volume útil de $8 \mathrm{~L}$. Cada saco plástico recebeu 1,5 litros de água sem cloro, contendo $3 \mathrm{~g}$ de sal/litro. A composição inicial da água usada nas embalagens foi: $\mathrm{OD}=7,0 \mathrm{mg} / \mathrm{L} ; \mathrm{CO}_{2}=6,0 \mathrm{mg} / \mathrm{L} ; \mathrm{pH}=$ 7,5 ; Temperatura $=25,6^{\circ} \mathrm{C} ; \mathrm{NH}_{3 \text { total }}=0,4 \mathrm{mg} / \mathrm{L} ; \mathrm{NH}_{3}=0,002 \mathrm{mg} / \mathrm{L} ;$ Alcalinidade $=$ $38 \mathrm{mg} / \mathrm{L}$ e Dureza $=96 \mathrm{mg} / \mathrm{L}$.

\section{Cargas de peixes e doses do anestésico}

Duas cargas de peixes $(235 \mathrm{~g}$ e $470 \mathrm{~g}$ de peixe/litro de água, o correspondente a 75 ou 150 peixes por embalagem) e 3 doses de benzocaína $(0,10$ e $20 \mathrm{mg} / \mathrm{L})$, foram avaliadas em um arranjo fatorial, com 3 repetições para cada um dos tratamentos. Através de um ensaio prévio, o efeito de diversas doses da benzocaina na sedação de alevinos de tilápia foi avaliado. Neste bionesaio, as doses de 10 e $20 \mathrm{mg} / \mathrm{L}$ foram as que levaram os peixes a um nivel de sedação adequado para o transporte. Assim, o anestésico benzocaina foi previamente dissolvido em álcool etílico, obtendo-se uma solução estoque com $10 \mathrm{mg}$ de benzocaína/mL. Quantidades suficientes da solução estoque foram adicionadas à água das embalagens, antes da estocagem dos peixes, de forma a obter as concentrações desejadas do anestésico. Imediatamente após a estocagem dos peixes, todo $o$ ar contido no interior das embalagens foi 
eliminado e o volume restante da embalagem foi completado com oxigênio. As embalagens foram fechadas com tiras de borracha e colocadas em caixas de papelão, para diminuir a influência da luz e de outros agentes externos.

\section{Variáveis avaliadas}

Em cada uma das embalagens foi registrado o tempo de transporte no qual os peixes começaram a demonstrar sinais de dificuldades respiratórias, com peixes boquejando na superfície da água nas embalagens. Neste momento as embalagens foram abertas para a avaliação dos parâmetros de qualidade da água, conforme especificados a seguir: 1) temperatura e oxigênio dissolvido (monitorados com medidor de oxigênio YSI Modelo 55); 2) $\mathrm{pH}$ (monitorado com o medidor de $\mathrm{pH}$ digital Hanna); 3) amônia total $-\mathrm{NH}_{3}$ total, amônia tóxica $-\mathrm{NH}_{3}$, gás carbônico $-\mathrm{CO}_{2}$, alcalinidade total e dureza total (analisados com o uso do kit Hach modelo FF2).

\section{Análises estatísticas}

O bioensaio foi constituído por 6 tratamentos e 3 repetições, em um delineamento experimental inteiramente casualizado, em arranjo fatorial. A análise dos dados se destinou a avaliar o efeito de três doses de benzocaína e duas cargas de peixes como fatores isolados, bem como as interações entre estes fatores. As ferramentas utilizadas para a análise foram: Proc Glm (análise da variância e comparação de médias através do teste de Tukey para os dados finais de tempo, $\mathrm{OD}, \mathrm{pH}$, temperatura, $\mathrm{CO}_{2}, \mathrm{NH}_{3}$ total e $\mathrm{NH}_{3}$ ) e Proc corr (análise de correlação de Spearman) do pacote de análises estatísticas SAS.

\section{Resultados}

Do início ao final do experimento a concentração de $\mathrm{CO}_{2}$ subiu dos iniciais $6 \mathrm{mg} / \mathrm{L}$ para 129 a $214 \mathrm{mg} / \mathrm{L}$. Embora pouca variação foi observada na 
temperatura da água, que girou entre 25,3 e $26,0^{\circ} \mathrm{C}, \mathrm{o} \mathrm{pH}$ foi reduzido do valor inicial de 7,5 para valores entre 5,3 e 5,7 ao final do experimento. Estas alterações no $\mathrm{pH}$ da água se relacionam às elevadas concentrações de $\mathrm{CO}_{2} \mathrm{em}$ todas as embalagens. Mesmo as embalagens com maiores concentrações apresentaram o mesmo valor médio no final do bioensaio. $\mathrm{A} \mathrm{NH}_{3}$ total, dos inciais $0,4 \mathrm{mg} / \mathrm{L}$ chegou a valores de 65 a $91 \mathrm{mg} / \mathrm{L}$. Apesar dos elevados valores de $\mathrm{NH}_{3}$ total, a amônia tóxica $\left(\mathrm{NH}_{3}\right)$ ficou dentro de limites aceitáveis, entre 0,037 e 0,051 mg/L (Tabela 1).

Independente das doses de benzocaína usadas, os peixes transportados nas embalagens contendo $470 \mathrm{~g} / \mathrm{L}$ apresentaram sinais de estresse por asfixia (boquejamento) com um tempo médio de transporte de 11:15 horas, contra $13: 19$ horas para os peixes transportados a $235 \mathrm{~g} / \mathrm{L}$, conforme ilustrado na Figura $1(P<0,05)$. Diferenças significativas também foram observadas nas concentrações médias de OD (8,21 vs $10,43 \mathrm{mg} / \mathrm{L}$; Figura 2), $\mathrm{CO}_{2}$ (207 vs $131 \mathrm{mg} / \mathrm{L}$; Figura 3), $\mathrm{NH}_{3}$ total (85 vs $67 \mathrm{mg} / \mathrm{L}$; Figura 4) e $\mathrm{NH}_{3}(0,047$ vs $0,038 \mathrm{mg} / \mathrm{L}$; Figura 5) entre as águas das embalagens estocadas com $470 \mathrm{e}$ $235 \mathrm{~g}$ de peixes $/ \mathrm{L}$, respectivamente $(P<0,05)$. Diferenças quanto à temperatura e o $\mathrm{pH}$ da água não foram significativas $(P>0,05)$.

As concentrações médias de OD final para a primeira carga de transporte não difereiram entre si. Entretanto, o mesmo não foi observado nos os tratamentos com $435 \mathrm{~g}$ de peixe/L (Figura 2).

Quando o efeito das doses de benzocaína foi avaliado de forma isolada, somente foram observadas diferenças significativas para as concentrações de $\mathrm{NH}_{3}$ total em ambas as cargas de transporte $(P<0,05)$. De uma maneira geral, houve uma tendência na redução dos niveis de $\mathrm{NH}_{3}$ total com o aumento da dose da benzocaína, notadamente na carga $470 \mathrm{~g}$ de peixe/L.

A sobrevivência dos peixes 48 horas após o transporte variou entre 98 e $100 \%$, não sendo detectadas diferenças significativas entre os tratamentos $(P>0,05)$. Os resultados da análise de correlação de Spearman foram utilizados para auxiliar na interpretação dos dados. 


\section{Discussão}

Diferente do que foi observado por Ferreira et al. (1984) e por Wedemeyer (1997), no presente estudo, não foram evidentes os efeitos esperados do uso da benzocaína na redução do consumo de oxigênio e dos níveis de gás carbônico e da amônia na água de transporte. Este resultado foi condizente com o observado por Carneiro e Urbinati (1999) em estudo sobre transporte de matrinxã (Brycon cephalus) em caixas de transporte.

Para a carga $470 \mathrm{~g}$ de peixe/L, os níveis de OD ao final do transporte, para as doses 10 e $20 \mathrm{mg} / \mathrm{L}$ foram inferiores ao observado no tratamento sem uso de anestésico. Este resultado diverge do que era esperado antes do início do experimento. Por outro lado, os níveis de $\mathrm{NH}_{3}$ total nas embalagens sem uso de anestésico ficaram acima dos valores obtidos nas embalagens com uso de benzocaína, conforme esperado. O objetivo inicial do uso das diferentes doses de benzocaína estava em avaliar o efeito da redução na atividade metabólica, bem como nas taxas de consumo de OD e excreção de metabolitos. Entretanto, através dos resultados apresentados, foi possivel notar que houve um pequeno aumento na taxa de consumo de OD e um decréscimo na taxa de excreção de metabolitos nitrogenados com o aumento da dose nas embalagens.

A hipótese de que o grau de sedação das doses testadas tenha levado os a uma peixes hiperatividade poderia ser utilizada para explicar o maior consumo de oxigênio dentro das embalagens contendo anestésico (Ferreira, 1982 citado por Ferreira et al., 1984). Entretanto, o fenômeno de hiperatividade acarretaria também um aumento na taxa de excreção de $\mathrm{CO}_{2}$ e metabolitos nitrogenados. Como os dados observados não apresentaram esta relação, esta hipótese deve ser descartada.

Segundo Ferreira et al. (1981), altas concentrações de $\mathrm{CO}_{2}$ na água estão associadas à anestesia dos peixes com a benzocaína. No entanto, no presente estudo a excreção de $\mathrm{CO}_{2}$ na água não foi afetada pelo uso do anestésico. 
Duas hipóteses podem explicar a não observação dos efeitos esperados com o uso do anestésico neste estudo. Ambas estão relacionadas com as elevadas cargas de peixes avaliadas. A primeira hipótese se baseia nas altas concentrações de gás carbônico na água, que ao final do transporte chegaram aos nívies de 131 a $207 \mathrm{mg} / \mathrm{L}$. Este nívies estão próximos dos sugeridos por Gilderhus e Marking (1987) como sendo de efeito anestésicos aos peixes (120 a $150 \mathrm{mg} / \mathrm{L}$ para alevinos, e 230 a $280 \mathrm{mg} / \mathrm{L}$ para peixes adultos).

A segunda hipótese seria que, sob as elevadas cargas de peixes testadas, a benzocaina teria sido rapidamente metabolizada, resultando em um efeito pouco durador da anestesia. Ferreira et. al. (1984), no transporte de alevinos de Oreochromis mossambicus, a uma temperatura de $25,0 \pm 1^{\circ} \mathrm{C}$ observou $\mathrm{O}$ efeito benéfico do uso da dose de $25 \mathrm{mg}$ de benzocaina/L para cargas de peixes de 2,4 e 4,8 g/L. Estas cargas representam 1\% das cargas testadas neste bioensaio, o que reforça esta segunda hipótese.

\section{Conclusão}

Sob as condições experimentais deste trabalho, não foram observadas grandes vantagens do uso de benzocaina no transporte de alevinos de tilápia em sacos plásticos. No entanto, doses mais elevadas deste anestésico devem ser reavaliadas mantendo-se as mesmas cargas de transporte.

\section{Agradecimentos}

Agradecemos à Piscicultura Paulista - Piracicaba, SP por ter cedido os alevinos de tilápia do Nilo para a execução deste bioensaio. 


\section{Referências bibliográficas}

CARNEIRO, P. C.; URBINATI, E. C. Stress e crescimento de peixes em piscicultura intensiva. In: SIMPÓSIO SOBRE MANEJO E NUTRIÇÃO DE PEIXES, Campinas, 1999. Anais. Campinas: CBNA, 1999, p. 25-40.

DURVE, V. S. Anaesthetics in the transport of mullet seed. Aquaculture, v. 5, p. 53-63, 1975.

FERREIRA, J. T.; SMIT, G. L.; SCHOONBEE, H. J. Hematological evaluation of the anaesthetic benzocaine hydrochloride in the freshwater fish Cyprinus carpio- L. Journal of Fish Biology, v. 18, n. 3, p. 291-297, 1981.

FERREIRA, J. T.; SCHOONBEE, H. J.; SMIT, G. L. The use of benzocainehydrochloride as an aid in the transport of fish. Aquaculture, v. 42, n. 2, p. 169-174, 1984.

GILDERHUS, P. A.; MARKING, P. A. Comparative efficacy od 16 ansthetic chemicals on rainbow trout. North American Journal of Fisheries Management, v. 7, p. 288-292, 1987.

GILDERHUS, P. A.; LEMM, C. A.; WOODS III, L. C. Benzocaine as an anesthetic for striped bass. The Progressive Fish Culturist, v. 53, p. 105107, 1991.

JENSEN, G. L. Transportation of warmwater fish: procedure and loading rates. Auburn: Auburn University, The Alabama Cooperative Extension Service, 1990a, 2p. (SRAC Publication, $n^{\circ} 392$ ).

PIPER, R. G.; McELWAIN, I. B.; ORME; L. E.; McCRAREN, J. P.; FOWLER, L. G.; LEONARD, J. R. Fish hatchery management. Washington, 1989. p. 348-371: Transportation of live fishes.

TAYLOR, A. L., SOLOMON, D. J. Critical factors in the transport of live freshwater fish - III. The use of anesthetics as tranquilizers. Fish. Management, v. 10, n. 4, p. $153-157,1979$. 
WEDEMEYER, G. A. Effects of rearing conditions on the health and physiological quality of fish min intesive culture. In: lawa, G. K.; Pickering, A. D.; Sumpter, J. P., Scherek, C. B. (ed). Fish stress and health in aquaculture. Cambridge: University Press, 1997, p. 35-71. 
Anexos B 


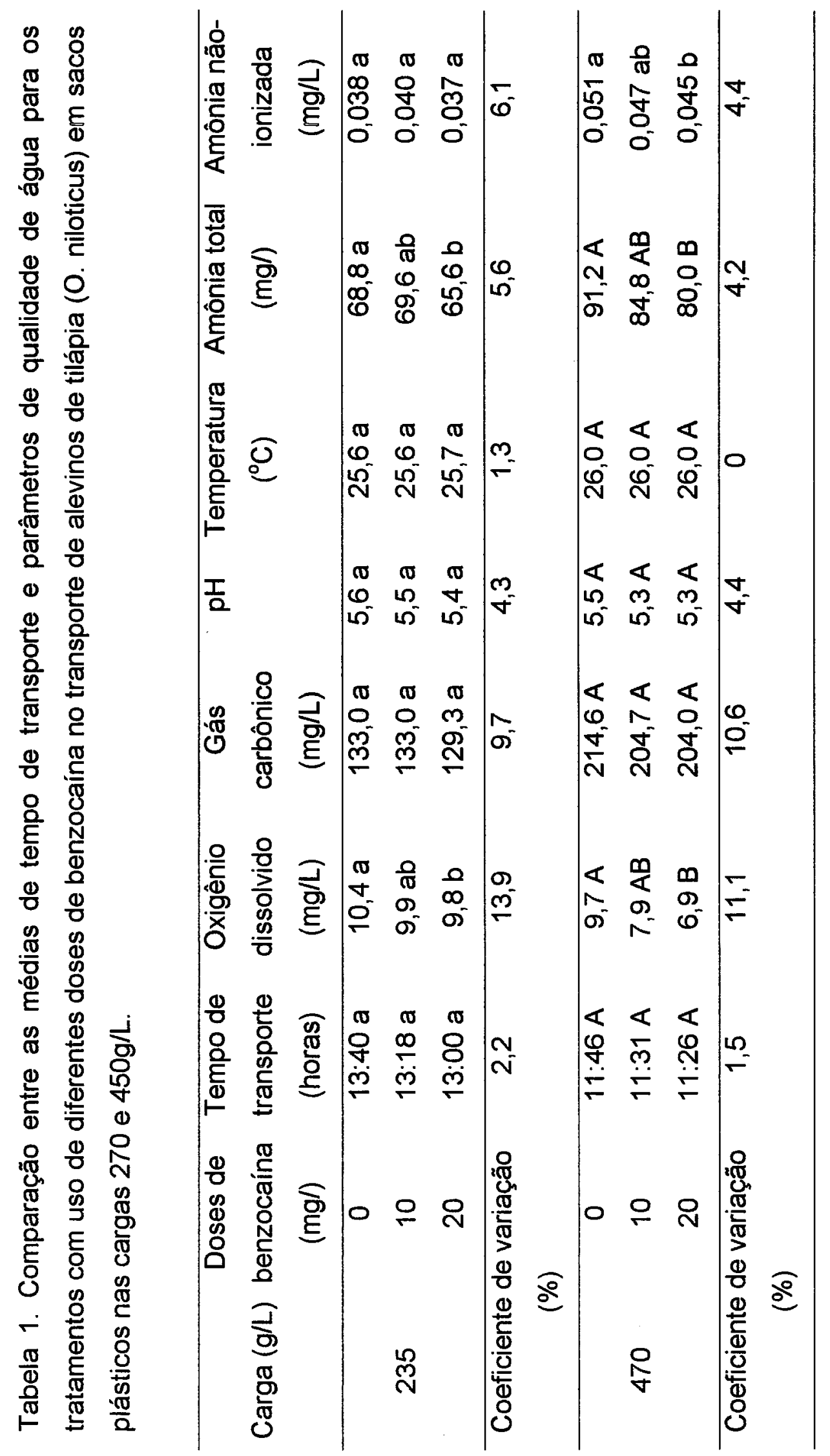




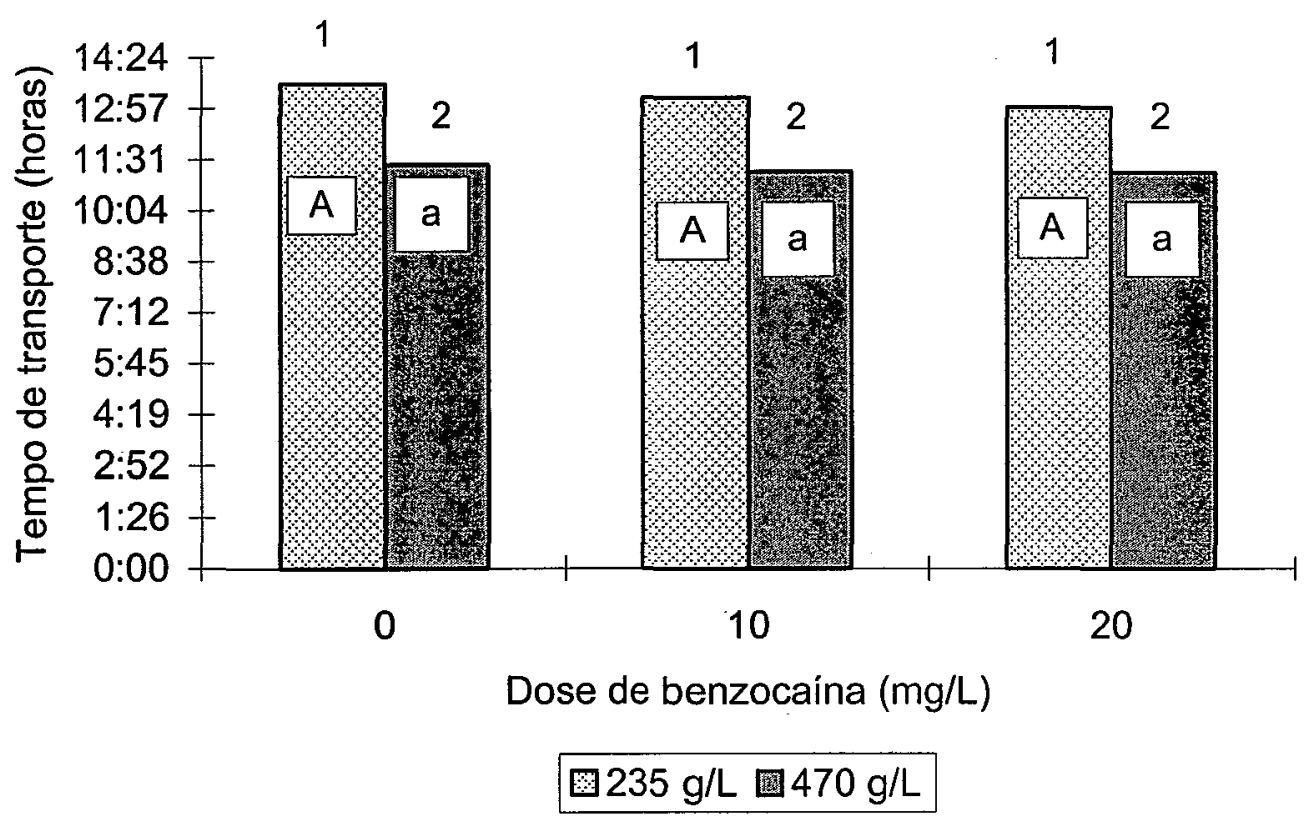

Figura 1. Comparação das médias de tempo de transporte para as cargas 235 e 470 $\mathrm{g} / \mathrm{L}$ (números) e para as diferentes doses de benzocaína dentro das referidas cargas (letras) - números e letras diferentes: $P<0,05$.

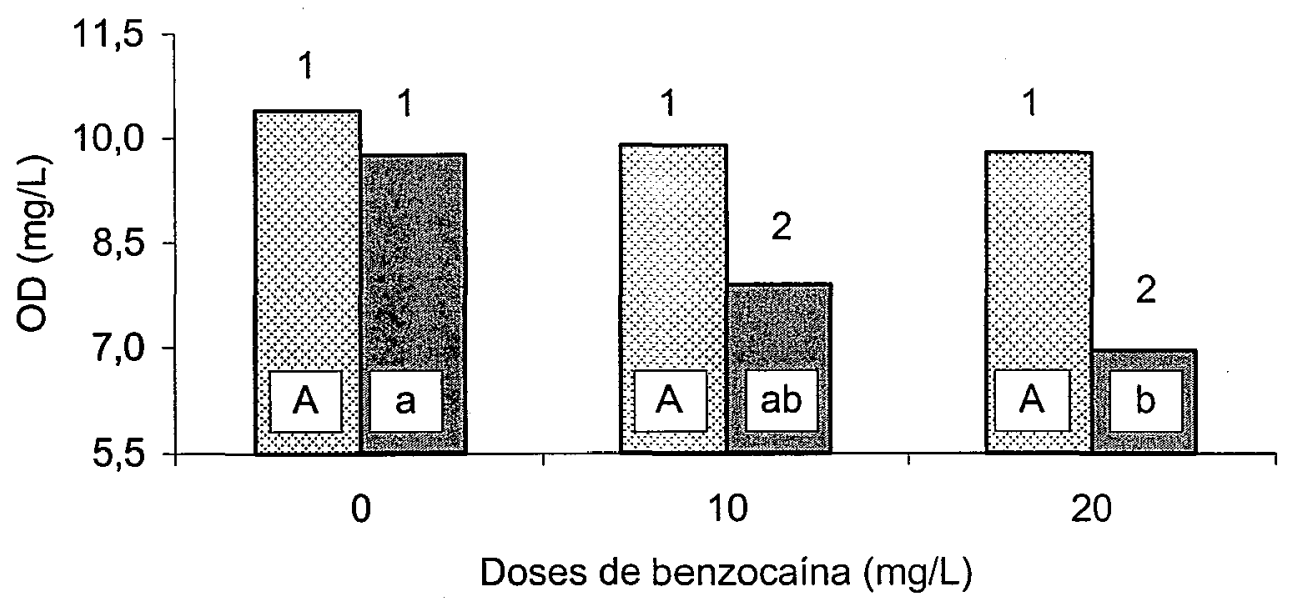

国235 g/L 圆 $470 \mathrm{~g} / \mathrm{L}$

Figura 2. Comparação das médias de oxigênio dissolvido na água do transporte para as cargas 235 e $470 \mathrm{~g} / \mathrm{L}$ (números) e para as diferentes doses de benzocaína dentro das referidas cargas (letras) números e letras diferentes: $P<0,05$. 


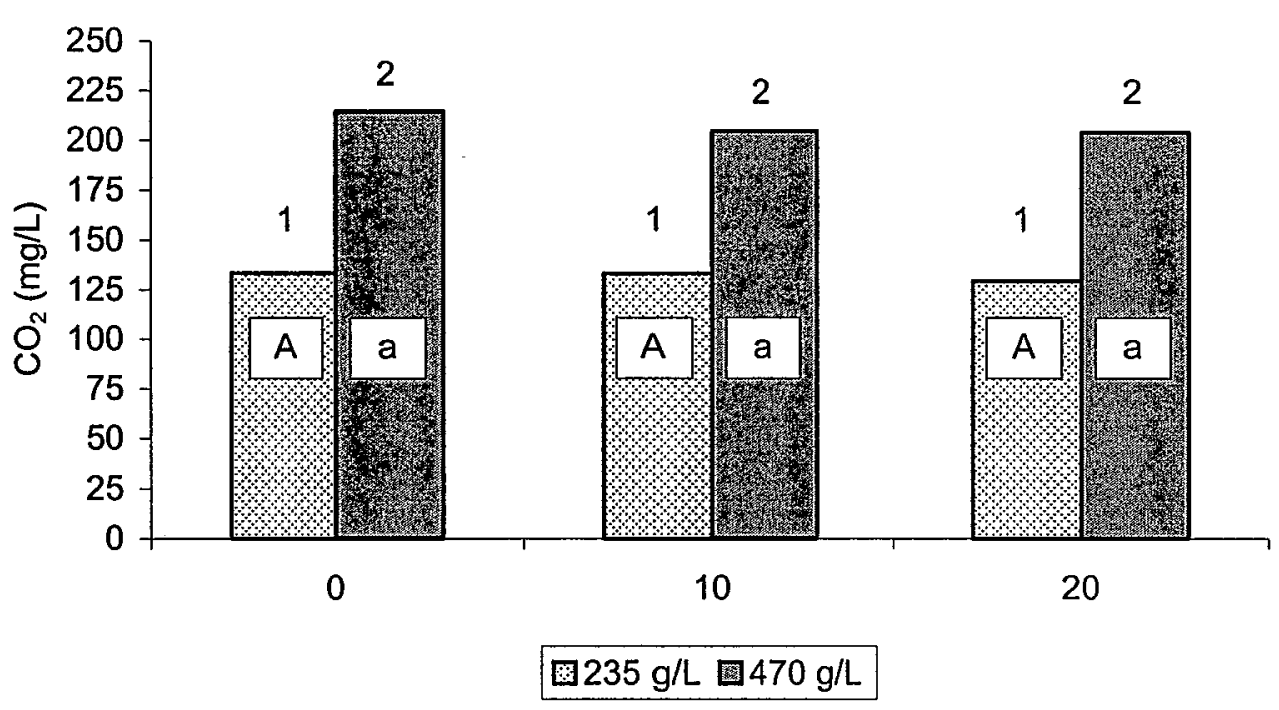

Figura 3. Comparação das médias de gás carbônico na água do transporte para as cargas 235 e $470 \mathrm{~g} / \mathrm{L}$ (números) e para as diferentes doses de benzocaina dentro das referidas cargas (letras) - números e letras diferentes: $P<0,05$.

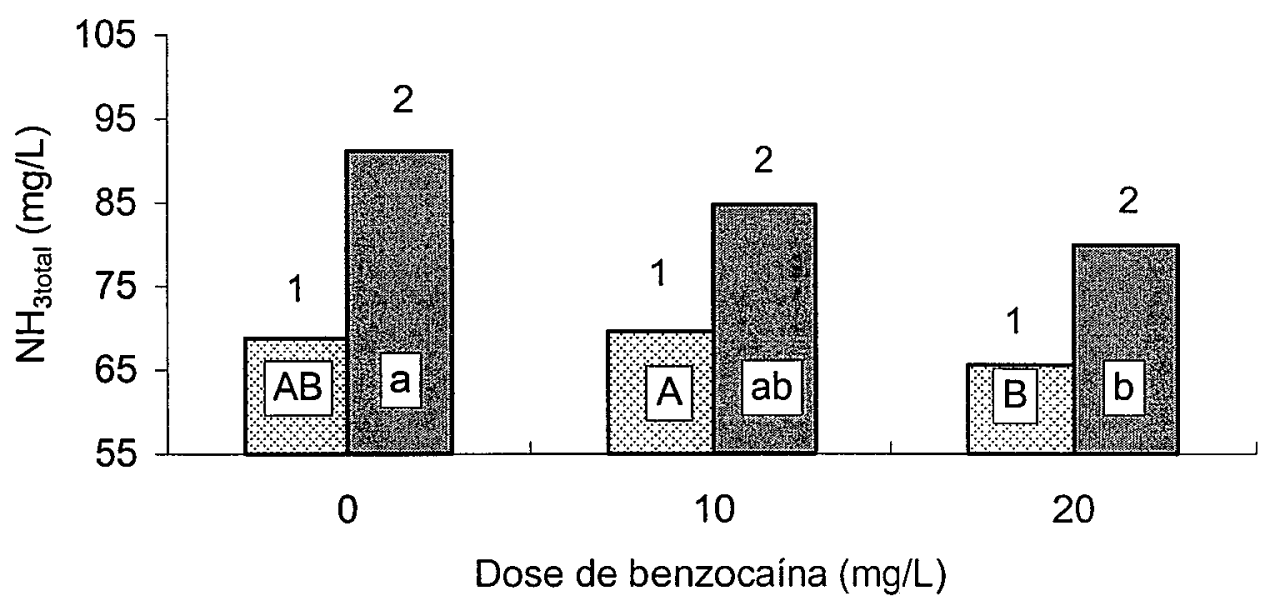

图235 g/L 圆470 g/L

Figura 4. Comparação das médias de amônia total na água do transporte para as cargas 235 e $470 \mathrm{~g} / \mathrm{L}$ (números) e para as diferentes doses de benzocaína dentro das referidas cargas (letras) - números e letras diferentes: $P<0,05$. 


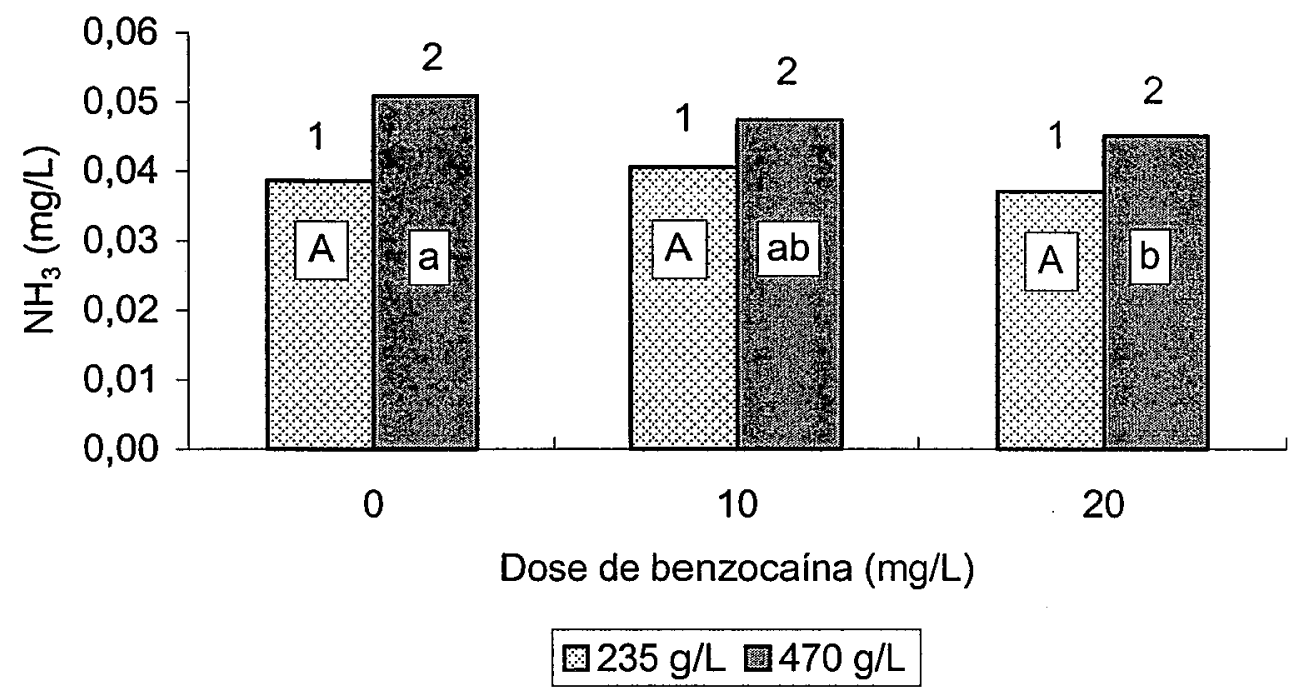

Figura 5. Comparação das médias de amônia tóxica na água do transporte para as cargas 235 e $470 \mathrm{~g} / \mathrm{L}$ (números) e para as diferentes doses dentro das referidas cargas (letras) - números e letras diferentes: $P<0,05$. 


\section{Capítulo 5. Conclusão geral}

Através da avaliação comparativa do transporte de alevinos de tilápia do Nilo (O. niloticus) entre peixes submetidos ao jejum e peixes sem jejum, foi possivel constatar um grande diferencial nos parâmetros de qualidade da água do transporte. Nas embalagens contendo peixes em jejum, os niveis finais de

$\mathrm{OD}$ foram maiores e as concentrações de $\mathrm{NH}_{3 \text { total, }} \mathrm{NH}_{3}$ e $\mathrm{CO}_{2}$ menores. Para uma mesma carga, esta diferença nos parâmetros de qualidade da água influenciaram no tempo de transporte. Desta forma, quando a idéia é de transportar peixes em sacos plásticos com a segurança de que os mesmos não morram devido a problemas de falta de $\mathrm{OD}$ ou excesso de $\mathrm{NH}_{3}$ e $\mathrm{CO}_{2}$, aconselha-se sempre submetê-los a um periodo de jejum tal qual permita esvaziamento do trato digestivo.

No experimento comparando o efeito de diferentes doses de benzocaína no transporte de alevinos de tilápia do Nilo (O. niloticus) não foi possível constatar efeito benéfico do anestésico para o tempo de transporte, niveis de $\mathrm{OD}$ na água e excreção de $\mathrm{CO}_{2}$ nos sacos plásticos. $A$ única vantagem do uso destas substâncias esteve na tendência de redução nas taxas de excreção de amônia com o aumento da dose de benzocaína para a maior carga. $\dot{E}$ bastante provável que o efeito "sedativo" do $\mathrm{CO}_{2}$ para os peixes tenha interferido nos resultados, uma vez que as concentrações observadas na água do transporte estavam dentro da recomendação para sedação em alevinos Em suma, para o bioensaio em questão, não foi observado o efeito benéfico do uso das doses 10 e $20 \mathrm{mg} / \mathrm{L}$ de benzocaína no transporte de alevinos de tilápia em sacos plásticos. 


\section{Referências bibliográficas}

ANDRIGUETTO, J. M.; PERLY, L.; MAINARDI, I.; GEMAEL, A. FLEMMING, J. S.; DE SOUZA, G. A.; BONA FILHO; A. Nutrição Animal. $4^{a}$ edição. São Paulo: Nobel. 1996, v. 11, 394p.

AMEND, D. F.; CROY, R. T.; GOVEN, B. A.; JOHSON, K. A; MCCARTHY, D. H. Transportation of fish in closed systems: methods to control ammonia, carbon dioxide, $\mathrm{pH}$ and bacterial growth. Transacations of American Fisheries Society. v. 111, p. 603-611, 1982.

BARTON, B. A.; SCHRECK, C. B.; FOWLER, L. G. Fasting and diet content affect stress-induced changes in plasma glucose and cortisol in juvenile chinook salmon. Progressive Fish Culturist. v. 50, n. 1, p. 16-22, 1988.

BEERLI, E. L.; LOGATO, P. V. R. Peixes de importância para a piscicultura brasileira. Boletim Técnico da Universidade Ferderal de Lavras, n. 42, 35 p., 1999.

BOCEK, A. Transporting fish. Auburn: Auburn University, International Center for Aquaculture and Aquatic Environments, 1996. 16p.

BOOKE, H. E.; HOLLENDER, B.; LUTTERBIE, G. Sodium bicarbonate, an inexpensive fish anesthetic for field use. The Progressive Fish Culturist, v.40, n.1, p. 11-13, 1978.

BOWER, C. E.; TURNER, D. T. Ammonia removal by clinoptilolite in the transport of ornamental freshwater fishes. Progressive Fish Culturist. v. 44, n. 1 , p. $19-23,1982$.

BOYD, C. E. Water quality in ponds for aquaculture. Auburn: Auburn University, 1996. $482 \mathrm{p}$. 
BRASIL. Ministério da Agricultura. Pesca e aqucicultura. http:// www.agricultura.gov.br/estatisticas/33.htm (21 out. 2000).

BROWN, J. A. G.; JONES, A.; MATTY. A J. Oxygem metabolism of farmed turbot (Scophthalmus maximus). I. the influence of fish size and water temperature on metabolic rate. Aquaculture, v.36, n.3, p.273-282, 1984.

CARMICHAEL, G. J.; TOMASSO, J. R.. Guidelines for handling and hauling largemouth bass. San Marcos: United States Fish and wild life Service, p. 26-29 (s. data).

CARMICHAEL, G. J.; WEDMEYER, G. A.; MCCRAEN, J. D.; MILLARD, J. L.

Physiological effects of handling and hauling stress on smallmouth bass. Progressive Fish Culturist, v.45, p.110-113, 1983

CARMICHAEL, G. J. Long distance truck transport of intensively reared largemouth bass. Progressive Fish Culturist, v.46, p. 111-115, 1984.

CARMICHAEL, G. J.; TOMASSO, J. R.; SIMCO, B. A.; DAVIS, K. B. Characterization and alleviation of stress with hauling largemouth bass. Transactions of American Fisheries Society, v.113, p. 778-785, 1984a.

CARMICHAEL, G. J; TOMASSO, J. R.; SIMCO, B. A.; DAVIS, K. B. Confinement and water quality-induced stress in largemouth bass. Transaction of American Fisheries Society, v.113, p.767-777, 1984b.

CARMICHAEL, G. J.; TOMASSO, J. R. Survey of fish transportation equipment and techniques. The Progressive Fish Culturist, v.50, p. 155-159, 1988.

CARNEIRO, P. C.; URBINATI, E. C. Stress e crescimento de peixes em piscicultura intensiva. In: SIMPÓSIO SOBRE MANEJO E NUTRIÇÃO DE PEIXES, Campinas, 1999. Anais. Campinas: CBNA, 1999. p. 25-40.

CASTAGNOLLI, N. Piscicultura de água doce. Jaboticabal: Funep, 1992. $189 \mathrm{p}$.

CASTAGNOLLI, N.. Situação atual e perspectivas da Aquicultura no Brasil. In: SIMPÓSIO INTERNACIONAL SOBRE NUTRIÇÃO DE PEIXES E CRUSTÁCEOS, Campos do Jordão, 1995. Anais. Campos do Jordão: CBNA, 1995. p. 1-18. 
CASTELLINI, M. A.; REA, L. D. The biochemistry of natural fasting and its limits. Experientia, v. 48, p. 575-582, 1992.

DURVE, V. S. Anaesthetics in the transport of mullet seed. Aquaculture. v. 5, p. 53-63, 1975.

FAO. Freshwater fishes production. http://apps.fao.org/fishery/fprod1-e.htm (21 out. 2000)

FARBRIDGE, K. J.; LEATHERLAND, J. F. Plasma growth hormone levels in fed and fasted rainbow trout (Oncorhynchus mykiss) are decreased following handling stress. Fish Physiology and Biochemistry, v. 10, n. 1, p. 67-73, 1992.

FERREIRA, J. T.; SMIT, G. L.; SCHOONBEE, H. J. Hematological evaluation of the anaesthetic benzocaine hydrochloride in the freshwater fish Cyprinus carpio- L. Journal of Fish Biology, v. 18, n. 3, p. 291-297, 1981.

FERREIRA, J. T.; SCHOONBEE, H. J.; SMIT, G. L. The use of benzocainehydrochloride as an aid in the transport of fish. Aquaculture. v. 42, n. 2 , p. 169-174, 1984.

FITZSIMMONS, K. The most important Aquaculture Species of thre $21^{\text {st }}$ century. In: Fitzsimmons, K.; Carvalho Filho, J. (ed). Proceedings from the Fifth International Symposium on Tilapia Aquaculture. September, 3-7, p. 3-8, 2000.

FLOYD, R. F. Stress - its role in fish diseases. Florida: University of Florida, Florida Cooperative Extension Service, Institute of Food and Agricultural Sciences, (s. data) 4p. (Circular, 919)

FORSBERG, O. I. The impact of varying feeding regimes on oxygen consumption and excretion of carbon dioxide and nitrogen in post-smolt Atlantic salmon Salmo salar L. Aquaculture-Research., v. 28, n. 1, p. 2941, 1997.

FORSMAN, I.; VIRTANEN, E.; SALMINEN, M. Salt addition decreases transport stress in freshwater pike-perch. In: BERKA, R.; HILGE, V. (Ed.) 
Production enhancement in still-water pond culture. Rome: FAO, Research Institute of Fish Culture and Hydrobiology, 1990. v. 1, p. 84-86. FRANKFORT, K. Here are some tips for transporting fish safetely. Water Farming Journal, v.?, n.?, p. 13, Mar. 1989.

FRÖESE, R. Relationship between body weight and loadind densities in fish transport using the plastic bag method. Aquaculture and Fisheries Management, v. 19, p. 275-281, 1988.

FRÖSE, R. Improved fish transport in plastic bags. INCLARM Newsletter, v.?, n.?, p.8, Oct. 1985.

GÉlINEAU, A; MEDALE, F; BOUJARD, T. Effect of feeding time on postprandial nitrogen excretion and energy expenditure in rainbow trout. Journal of Fish Biology, v. 52, n. 4, p. 655-664, 1998.

GILDERHUS, P. A.; MARKING, P. A. Comparative efficacy od 16 ansthetic chemicals on rainbow trout. North American Journal of Fisheries Management, v. 7, p. 288-292, 1987.

GILDERHUS, P. A.; LEMM, C. A.; WOODS III, L. C. Benzocaine as an anesthetic for striped bass. The Progressive Fish Culturist, v. 53 , p. 105107, 1991.

GRIZZLE, J. M.; MAULDIN II, A. C.; YOUNG, D.; HENDERSON, E. Survival of juvenile striped bass (Morone saxatalis) and Morone hybrid bass (Morone chrysops $\times$ Morone saxatalis) increased by addition of calcium to soft water. Aquaculture, v.46, p.167-171, 1985.

HOWE, G. E.; BILLS, T. D.; MARKING, L. L. Removal of benzocaine from water by flitration with activated carbon. Progressive Fish Culturist, v. 52, p. 32-35, 1990.

IWAMA, G. K.; MCGEER, J. C.; PAWLUK, M. P. The effects of five fish anaesthetics on acid - base balance, hematocrit, blood gases, cortisol, and adrenaline in rainbow trout. Canadian Journal of Zoology, v. 67, n. 8, p. 2065-2073, 1989. 
JARBOE, H. H. Diel oxygen consumption and total ammonia nitrogen production by fingerling channel catfish following feeding at different times. The Progressive Fish Culturist, v. 57, p. 156-157, 1995.

JENSEN, G. L. Transportation of warmwater fish: procedure and loading rates. Auburn: Auburn University, The Alabama Cooperative Extension Service, 1990a. 2p. (SRAC Publication, 392)

JENSEN, J. Transportation of warmwater fish: loading rates and tips by species. Auburn: Auburn University, The Alabama Cooperative Extension Service, 1990b. 4p. (SRAC Publication, 393)

JOBLING, $M$. The influences of feeding on the metabolic rate of fishes: a short review. Journal of Fish Biology, v.18, p. 385-400, 1981.

JOHNSON, S. K. Transport of live fish. Cooperative Extension Work in Agriculture and Home Economics, FDDL-F14: 13p. March., 1979.

KUBITZA, F. Técnicas de transporte de peixes. Jundiai: F. Kubitza, 1999. $51 \mathrm{p}$.

KUBITZA, F. Tecnologia e planejamento na produção de tilápia. Jundiaí: $F$. Kubitza, 2000. 289p.

LIED, E.; BRATTON, B. The effect of feeding and starving, and different ratios of protein energy to total energy in feed excretion of amonia in Atlantic Cod (Gadus morhua). Comparative Biochemistry and Physiology, v. 78b, p. 49-52, 1984.

LINTIN, T. K; REID, S. D.; WOOD, C. M. The metabolic costs and physiological consequences to juvenile rainbow trout of a simulated summer warming scenario in the presence and absence of sublethal ammonia. Transactions of the American Fisheries Society, v. 126, p. 259-272, 1997.

LONG, C. W.; MCCOMAS, J. R.; MONK, B. H. Use of salt ( $\mathrm{NaCl})$ water to reduce mortality of chinook salmon smolts, Oncorhyncus tshawytscha, during handling and hauling. Marine Fish Review, v.39, p. 6-9, 1977. 
LOVSHIN, L. L. Worldwide tilapia culture. In: Anais do I Workshop Internacional de Aquicultura. São Paulo, SP. P. 96-116, 1997.

MATTSON, N. S.; RIPLE, T. H. Metomidate, a better anesthetic for cod (Gadus morhua ) in comparison with Benzocaine, MS-222, chlorobutanol, and phenoxyethanol. Aquaculture, v. 83, n. 1/2, p. 89-94, 1989.

MAZEAUD, M. M.; F. MAZEAUD; E. M. DONALDSON. Primary and secondary effects of stress in fish: some nemlw data with a general review. Transactions of the American Fisheries Society, v.106, n. 3, p. 201-212, 1977.

MAZIK, P. M.; SIMCO, B. A., PARKER, N. C. Influence od water hardness and salts on survival and physiological characteristics of striped bass during and after transport. Transactions of the American Fisheries Society, v. 120, p. 121-126, 1991.

MCCRAREN, J. P.; J. L. MILLARD. Manual of fish culture. Section G: Fish transportation. San Marcos, 1978. p. 44-88: Transportation of warwater fishes.

MCGEE, M.; C. CICHRA. Fish fingerlings: purchasing, transporting and stocking. University of Florida, Florida Cooperative Extension Service, Institute of Food and Agricultural Sciences, (s. data) 1p.

MEHNER, T.; WIESER, W. Energetics and metabolic correlates of starvation in juvenile perch (Perca fluviatilis). Journal of Fish Biology, v. 45, n. 2, p. 325-333, 1994.

MEINERTZ, J. R.; STEHLY, G. R.; GINGERICH, W. H. Pharmacokinetics of benzocaine in rainbow trout (Oncorhynchus mykiss) after intraarterial dosing. Aquaculture, v. 148, p. 39-48, 1996.

MÉNDEZ, G.; WEISER,W. Metabolic responses to food deprivation and refeeding in juveniles of Rutilus rutilus (Teleostei: Cyprinidae). Environmental Biology of Fishes, v. 36, n. 1, p. 73-81, 1993. 
MOMMSEN, T. P.; WALSH, P. J. Biochemical and environmental perspectives on nitrogen metabolism in fishes. Experientia, v. 48, p. 583-593, 1992.

NIKINMAA, M.; SOIVIO, A.; NAKARI, T.; LINDGREN, S. Hauling stress in brown trout (Salmo trutta): physiological responses to transport in freshwater or salt water, and recovery in natural brackwish water. Aquaculture, v.34, p. 93-99, 1983.

PARMA-DE-CROUX, M. J. Benzocaine (ethyl-p-aminobenzoate) as an anaesthetic for Prochilodus lineatus Valenciennes (Pisces, Curimatidae). Journal of Applied Ichthyology, v. 6, n. 3, p. 189-192, 1990.

PIPER, R. G.; I. B. MCELWAIN; L. E. ORME; J. P. MCCRAREN; L. G. FOWLER; J. R. LEONARD. Fish hatchery management. Washington, 1989. p.348-371: Transportation of live fishes.

POPMA, T. J.; LOVSHIN, L. L. Worldwide prospects for commercial production of tilapia. Auburn: International Center for Aquaculture and Aquatic Environments, 1996. 23 p. (Research and Development Series, 41)

POST, G. Textbook of fish health. Orlando: T.F.H. Publications, 1987. 288p. RANDALL, D. Gas exchange in fish. In: HOAR, W. S.; RANDALL, D. J.(ed) Fish Physiology. Orlando: Academic Press, 1984, v. X, cap. 7, p. 253$292 p$.

RANDALL, D. J.; WRIGHT, P. A. The interaction Between carbon dioxide and ammonia excretion and water $\mathrm{pH}$ in fish. Canadian Journal of Zoology, v.67, p. 2936-2942, 1989.

REDDING, J. M.; SCHERECK, C. B. Influence of ambient salinity on osmorregulation and cortisol concentration in yearling Coho salmon during stress. Transactions of the American Fisheries Society, v. 112, p. 800$807,1983$.

ROSS, L. G. , GEDDES, J. A. Sedation of warm water fish species in aquaculture research. Aquaculture, v. 16, p. 183-186, 1979. 
ROSS, B.; ROSS, L. G. The oxygen requirements of Oreochromis niloticus under adverse conditions. In: International Symposium on Tilapia Aquaculture. Edited by: Fishelson, L.; Yaron, Z. Tel Aviv University Press, Israel. P. 134-143. 1983.

ROSS, L. G. Environmental physiology and energetics. In: Tilapias: biology and exploitation. Edited by: Beveridge, M. C. M; McAndrew, B. J. Dordrecht: Kluer Academic Publishers. v. 25, p. 89-128, 2000.

SAMPSON, D. R.T.; MACINTOSH, D. J. Transportation of live carp fry in sealed polythene bags. Aquaculture, v. 54, p. 123-127, 1986.

SNOW, J. R. Transporting egg, fry and fish. Producing and Marketing catfish in the Tennesee Valley. T. V. A. Conf. Proc. June 30 -Jully 1., 1971.

SOLOMON, D. J. ; L. TAYLOR. Critical factors in the transport of live freshwater fish - II State of feeding and ammonia excretion. Fish Management, v. 10, n. 2, p. 81-85, 1979.

STICKNEY, R. R. Culture of nonsalmonid freshwater fishes. Washington: University of Washington, 1986. ??? total de páginas.

SWAN, L. Transportation of fish in bags. Local: North Central Regional Aquaculture Center, 1992. 4 p. (Fact Sheet Series, 104)

SWANSON, C.; MAGER, R. C.; DOROSHOV, S. I.; CECH Jr., J. J. Use of salts, ansthetics and plymers to minimize handling and transport mortality in Delta Smelt. Transaction of the American Fisheries Society, v. 125, p. 326-329, 1996.

TAYLOR, A. L., SOLOMON, D. J. Critical factors in the transport of live freshwater fish - III. The use of anesthetics as tranquilizers. Fish. Management, v. 10, n. 4, p. $153-157,1979$

TAYLOR, A. L.; SOLOMON, D. J. Critical factors in the transport of living freshwater fish - I. General considerations and atmosferic gases. Fisheries Management, v. 10, n.1, p. 27-32, 1979.

TEO, L. H.; CHEN, T. W.; LEE, B. H. Packing of the guppy, Poecilia reticulata, for air transport in a closed system. Aquaculture, v.78, p.321-332, 1989. 
THOMPSON, I.; WHITE, A.; FLETCHER, T. C.; HOULIHAN, D. F.; SECOMBES, C. J. The effect of stress on the imune response of Atlantic salmon (Salmo salar L.) fed diets containing different amounts of vitamin C. Aquaculture, v.114, p.1-18, 1993

VIJAYAN, M. M.; MOON, T. W. Acute handling stress alters hepatic glycogen metabolism in food-deprived rainbow trout (Oncorhynchus mykiss). Canadian Journal of Fisheries and Aquatic Sciences, v. 49, n. 11, p. 2260-2266, 1992.

WEDEMEYER, G. A. Effects of rearing conditions on the health and physiological quality of fish min intesive culture. In: lawa, G. K.; Pickering, A. D.; Sumpter, J. P., Scherek, C. B. (ed). Fish stress and health in aquaculture. Cambridge: University Press, 1997, p. 35-71.

WURTS, W. A. Pure oxygen and live fish transport. Local: Kentucky State University, Kentucky Fish Farming, Cooperative Extension Program, 1990. $1 \mathrm{p}$.

WURTS, W. A. Using salts to reduce handling stress in channel catfish. World Aquaculture, v.26, n.3, p.80-81, 1995.

YANG, T. H.; SOMERO, G. N. Effects of feeding and food deprivation on oxygen consumption, muscle protein concentration and activities of energy metabolism enzymes in muscle and brain of shallow-living (Scorpaena guttata) and deep-living (Sebastolobus alascanus) Scorpaenid fishes. Journal of Experimental Biology, v. 181, p. 213-232, 1993.

YOSHIKAWA, H.; Y. YOKOYAMA, Y.; UENA, S.; MITSUDA, $H$. Changes of blood gas in carp, Cyprinus carpio, anesthetized with carbon dioxide. Comparative Biochemistry and Physiology, v. 98A, n. 3/4, p. 431-436, 1991. 